\title{
A Systematic Review of Metal Oxide Applications for Energy and Environmental Sustainability
}

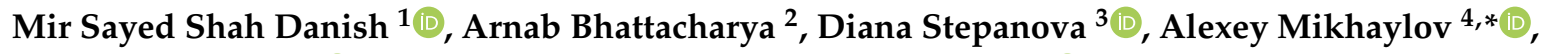 \\ Maria Luisa Grilli ${ }^{5}\left(\right.$, , Mahdi Khosravy ${ }^{6}$ and Tomonobu Senjyu ${ }^{7(-)}$ \\ 1 Strategic Research Projects Center, University of the Ryukyus, Nishihara 903-0213, Japan; \\ mdanish@lab.u-ryukyu.ac.jp \\ 2 Department of Academic Affairs, REPA—Research and Education Promotion Association, Naha 900-0015, \\ Japan; a.bhattacharya@repa.jp \\ 3 Department of Finance and Prices, Plekhanov Russian University of Economics, 117997 Moscow, Russia; \\ s_diana@mail.ru \\ 4 Department of Banking and Financial Markets, Financial University under the Government of the \\ Russian Federation, 124167 Moscow, Russia \\ 5 ENEA-Italian National Agency for New Technologies, Energy and Sustainable Economic Development, \\ Energy Technologies and Renewable Sources Department, Casaccia Research Center, Via Anguillarese 301, \\ 00123 Rome, Italy; marialuisa.grilli@enea.it \\ 6 Media Integrated Communication Laboratory, Graduate School of Engineering, Osaka University, \\ Osaka 565-0871, Japan; mkhosravy@lab.u-ryukyu.ac.jp \\ 7 Department of Electrical and Electronics Engineering, University of the Ryukyus, Nishihara 903-0213, Japan; \\ b985542@tec.u-ryukyu.ac.jp \\ * Correspondence: ayumihajlov@fa.ru
}

Received: 8 October 2020; Accepted: 26 November 2020; Published: 29 November 2020

\begin{abstract}
Energy is the fundamental requirement of all physical, chemical, and biological processes which are utilized for better living standards. The toll that the process of development takes on the environment and economic activity is evident from the arising concerns about sustaining the industrialization that has happened in the last centuries. The increase in carbon footprint and the large-scale pollution caused by industrialization has led researchers to think of new ways to sustain the developmental activities, whilst simultaneously minimizing the harming effects on the enviroment. Therefore, decarbonization strategies have become an important factor in industrial expansion, along with the invention of new catalytic methods for carrying out non-thermal reactions, energy storage methods and environmental remediation through the removal or breakdown of harmful chemicals released during manufacturing processes. The present article discusses the structural features and photocatalytic applications of a variety of metal oxide-based materials. Moreover, the practical applicability of these materials is also discussed, as well as the transition of production to an industrial scale. Consequently, this study deals with a concise framework to link metal oxide application options within energy, environmental and economic sustainability, exploring the footprint analysis as well.
\end{abstract}

Keywords: photocatalyst; nanocomposites; solar energy; multilayer metal oxides

\section{Introduction}

Metal oxides play a key role in environmental remediation and pollutant sensing and are strategic also in several other applications including energy production, conversion and storage. Metal oxides exhibit a great variety of functional properties, strongly dependending on their crystal structure, morphology, composition, intrinsic defects, doping, etc., which determine their optical, electrical, 
chemical and catalytic properties. Growth methods and process parameters strongly govern the morpho-structural characteristics and therefore the physico-chemical properties of metal oxides $[1,2]$. The band gap and electronic structure of oxides can be controlled and tailored by the size and dimension and this is the key to multifunctional possibilities presented by metal oxide-based materials. Modulating the bandgap and surface adsorption properties is essential for application in heterogeneous photocatalysts. The structural diversity of metal oxides is provided by both chemical and physical methods of synthesis, and by the process parameters. A lot of work has been reported in the green synthesis of metal oxide-based materials [3]. Recently, metal oxides' synthesis assisted by ionic lliquids (ILs) has been proposed to achieve oxides' production with controllable nanostructures (nanorods, nanospheres, core-shell nanostructures, etc.) and increased catalytic efficiency for air pollutant sensing and remediation. ILs ability to dissolve inorganic compounds can play a noteworthy role in producing highly dispersed composites, enhancing their activity [4].

The release of toxic and often difficult to degrade chemicals from industries producing pharmaceuticals, textiles and paints leads to large-scale water and soil pollution. In this regard, metal and metal oxide nanoparticles have been known to exhibit good photocatalytic properties for the degradation of such chemicals. An environmental remediation photocatalyst works by facilitating oxidation and reduction processes via trapping the light energy which leads to quick degradation of the targeted pollutants. Apart from common organic pollutants like dyes, other organic pollutants like antibiotics, PAHs, pesticides, and non-organic species such as heavy metals, radioactive metal compounds, sulfur compounds, and inorganic contaminants also need to be removed from water bodies. Environmental remediation also involves effective measures to monitor the levels of these pollutants in soil, water and air [5-8].

Concerning the energy applications, the photoelectrochemical (PEC) water splitting and the photocatalytic reduction of $\mathrm{CO}_{2}$ represent environmentally friendly and sustainable sources of hydrogen fuel and renewable fuels and chemicals, respectively. Metal oxide semiconductors play a key role in both applications, due to their photo-electrochemical stability, low cost, favorable band edge positions and bandgaps.

The present review deals with the recent advances in photocatalytic applications of selected metal oxides for pollution remediation and energy production. The study highlights how metal oxide are used in applications for energy and environmental sustainability, taking into account also the limit of their practical application on large scale.

\section{Literature Review}

\subsection{Metal Oxide-Based Materials}

Global indicators of sustainable development (evaluation of the influence of the human development index on consumption and quality of energy) was recently contributed by one of the authors of this manuscript $[9,10]$.

The applications of some of the representative metal oxide-based materials, characterized by different nanostructures, is shown in Table 1. The list of oxides reported in the table is not exhaustive, and the photocatalytic performaces of many other metal oxides will be be discussed in the next sections. As evident from the data presented in Table 1, the structure of the core and the functional materials are important in modulating the bandgap and the surface adsorption properties of these heterogeneous photocatalysts.

Bandgap modulation, microstructure and optoelectronic properties are fundamental for a wide range of metal oxide applications [11-17]. The structural diversity of metal oxides is provided by the method of synthesis among which the most common are co-precipitation, deposition, hydrothermal method, sol-gel method, soak-deoxidize-air oxidation, and impregnation. 
Figure 1, reports the variety of applications for metal oxide-based materials, including the photocatalytic applications for environmental remediation, decarbonization, and energy sustainability [18], which will be all discussed in the following sections.

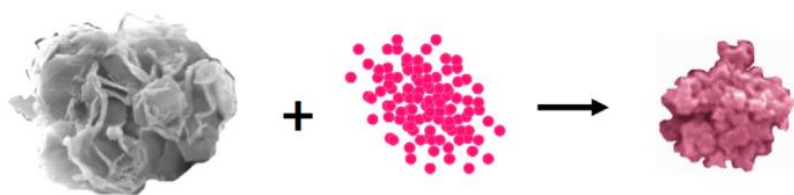

$\mathrm{ZnO}$ flowerlike architecture otriphenylmethane dye.

(a)

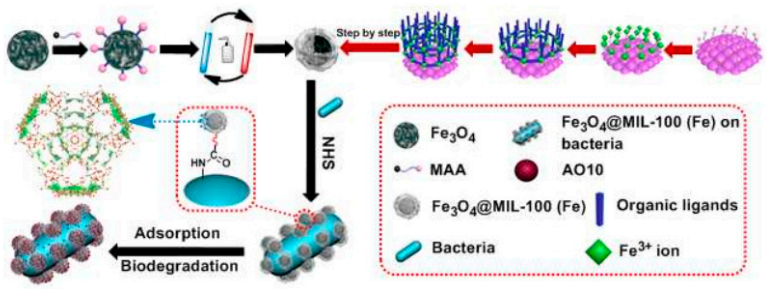

(b)

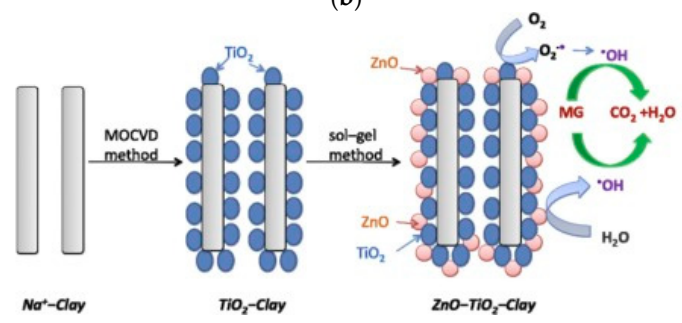

(c)

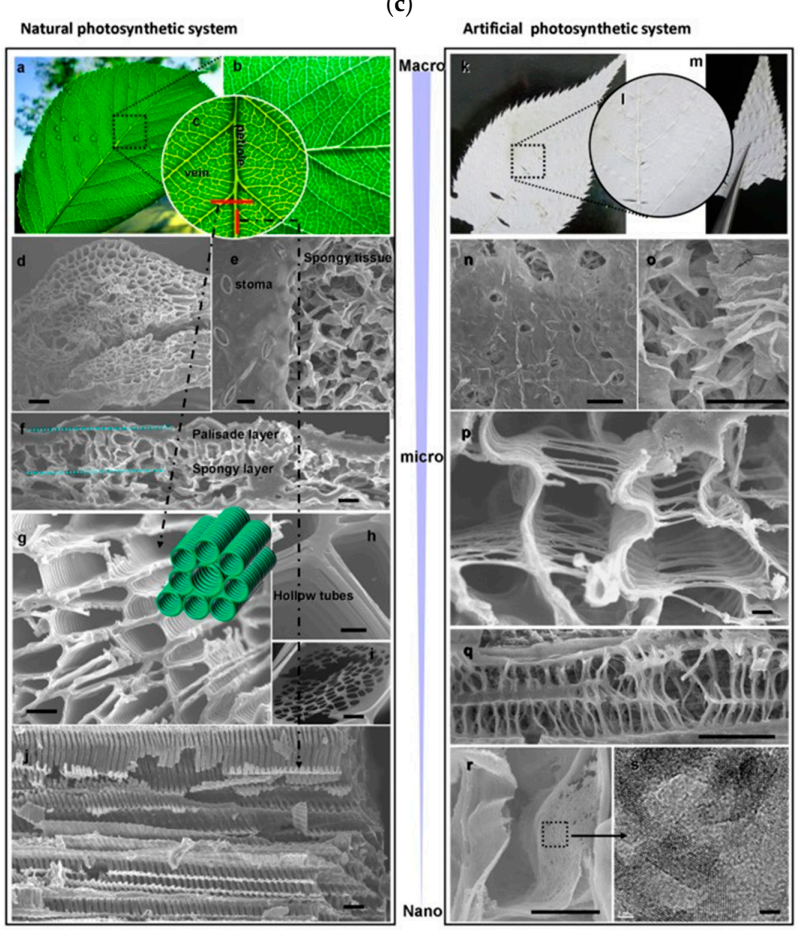

(d)

Figure 1. Structural influence of some metal oxide-based materials on their associated properties. (a) Absorption schematically presentation mechanism for triphenylmethane dyes on the $\mathrm{ZnO}$ flowerlike architectures. (b) $\mathrm{AO}_{10}$ biodegradation and adsorption using $\mathrm{Fe}_{3} \mathrm{O}_{4}$ MIL-100 (Fe) Core-Shell Bionanocomposites. (c) Design and application of $\mathrm{ZnO}-\mathrm{TiO}_{2} /$ clay. (d) Comparison of NPS (Cherry Blossom leaf) and APS (leaf-architectured $\mathrm{SrTiO}_{3}$ ) morphology at macro-, micro- and nanoscales. 
Table 1. Applications of some representative metal oxide-based materials with various structures.

\begin{tabular}{|c|c|c|c|c|}
\hline Metal Oxide-Based Material & Structural Features & Synthesis Method & Application & Ref. \\
\hline $\mathrm{ZnO}$ nanosheets & $\begin{array}{c}\text { 3D hierarchical flower-like } \\
\text { architectures }\end{array}$ & Solvothermal & $\begin{array}{c}\text { Adsorption of } \\
\text { triphenylmethane dyes }\end{array}$ & [5] \\
\hline $\mathrm{Fe}_{3} \mathrm{O}_{4} \mathrm{UiO}-66$ composite & Cubical NPs arranged & Sonication & Adsorption & [6] \\
\hline $\begin{array}{c}\mathrm{Fe}_{3} \mathrm{O}_{4} \mathrm{MIL}-100(\mathrm{Fe}) \text { Core-Shell } \\
\text { Bionanocomposites }\end{array}$ & $\begin{array}{c}\text { Core-shell structure with } \\
\mathrm{Fe}_{3} \mathrm{O}_{4} \text { core, immobilized on } \\
\text { P. Putida }\end{array}$ & $\begin{array}{l}\text { Sonication followed by } \\
\text { attaching the NPs on } \\
\text { bacteria }\end{array}$ & Adsorption & [7] \\
\hline $\mathrm{ZnO}-\mathrm{TiO}_{2} /$ clay & $\begin{array}{c}\mathrm{TiO}_{2} \text { and } \mathrm{ZnO} \text { NPs mounted } \\
\text { on clay surface }\end{array}$ & Sol-gel method & Degradation of MG & [8] \\
\hline $\mathrm{Cu} / \mathrm{ZnO} / \mathrm{Al}_{2} \mathrm{O}_{3}$ & $\begin{array}{c}\mathrm{Cu} \text { and } \mathrm{ZnO} \text { impregnated } \\
\gamma-\mathrm{Al}_{2} \mathrm{O}_{3}\end{array}$ & Impregnation method & $\begin{array}{l}\text { CO removal from reformed } \\
\text { fuel }\end{array}$ & [19] \\
\hline $\mathrm{Co}^{2+}, \mathrm{N}^{\mathrm{i} 2+}$ doped $\mathrm{Fe}_{3} \mathrm{O}_{4} \mathrm{NPs}$ & Cubic lattice & Co-precipitation method & $\begin{array}{l}\text { Photodegradation of Carbol } \\
\text { Fuchsin }\end{array}$ & [20] \\
\hline $\mathrm{Ce} / \mathrm{Fe}$ bimetallic oxides (CFBO) & $\begin{array}{l}\text { Flowerlike 3D hierarchical } \\
\text { architecture }\end{array}$ & $\begin{array}{l}\text { No-template hydrothermal } \\
\text { method }\end{array}$ & $\begin{array}{l}\mathrm{As}(\mathrm{V}) \text { and } \mathrm{Cr}(\mathrm{VI}) \\
\text { remediation }\end{array}$ & [21] \\
\hline $\begin{array}{l}\text { Perovskite titanates }\left(\mathrm{ATiO}_{3}, \mathrm{~A}=\mathrm{Sr} \text {, }\right. \\
\mathrm{Ca} \text { and } \mathrm{Pb})\end{array}$ & $\begin{array}{l}\text { Leaf-architectured 3D } \\
\text { Hierarchical structure }\end{array}$ & $\begin{array}{l}\text { Combination of biosynthesis } \\
\text { from Cherry Blossom, } \\
\text { heating, grinding and } \\
\text { photodeposition }\end{array}$ & $\begin{array}{l}\text { Artificial Photosynthetic } \\
\text { System for photoreduction } \\
\text { of } \mathrm{CO}_{2}\end{array}$ & [22] \\
\hline $\mathrm{TiO}_{2}$ polypyrrole & Core shell nanowires (NWs) & $\begin{array}{l}\text { Seed-assisted hydrothermal } \\
\text { method }\end{array}$ & $\begin{array}{l}\text { Flexible supercapacitors } \\
\text { (SCs) on carbon cloth }\end{array}$ & [23] \\
\hline $\mathrm{Fe}_{3} \mathrm{O}_{4} / \mathrm{WO}_{3}$ & $\begin{array}{l}\text { Hierarchical Core shell } \\
\text { Structure }\end{array}$ & $\begin{array}{l}\text { Solvotermal growth }+ \\
\text { oxidation route }\end{array}$ & $\begin{array}{l}\text { photodegradation of } \\
\text { organic-dye materials }\end{array}$ & [24] \\
\hline
\end{tabular}

Among the two ways in which catalysts can alter any reaction, i.e., lowering the activation energy and providing an alternate pathway, the metal oxide-based photocatalysts seem to do both for dye and other organic pollutant degradation. The whole phenomenon usually takes three important steps-separation of the electron-hole charge carriers, distribution of these charge carriers over the whole surface of the catalyst, and thirdly, binding the organic molecules onto the active sites to carry forward the redox processes. Generally, $\mathrm{H}_{2} \mathrm{O}_{2},{ }^{\circ} \mathrm{OH},{ }^{\circ} \mathrm{OOH}$ and $\mathrm{O}_{2}{ }^{\circ-}$ are the species that are most reactive in carrying out the degradation reactions [25]. The typical participation of a photocatalyst in the degradation of organic molecules is shown below:

$$
\begin{gathered}
\text { Photocatalyst } \stackrel{\text { hv }}{\rightarrow} \mathrm{e}^{-} \mathrm{CB}+\mathrm{h}_{\mathrm{VB}}^{+} \\
\mathrm{O}_{2}{ }^{-}+2 \mathrm{e}^{-} \mathrm{CB}+2 \mathrm{H}^{+} \rightarrow{ }^{\circ} \mathrm{OH}+\mathrm{OH}^{-} \\
\mathrm{h}^{+}{ }_{\mathrm{VB}}+\mathrm{H}_{2} \mathrm{O} \rightarrow \mathrm{H}^{+}+{ }^{\circ} \mathrm{OH} \\
\text { Organic Pollutants }+{ }^{\circ} \mathrm{OH} \rightarrow \mathrm{CO}_{2}+\mathrm{H}_{2} \mathrm{O}
\end{gathered}
$$

Metal oxide photocatalysts are one of the prime examples of this type of catalyst that can release the reactive radicals to target the organic pollutants present in aqueous media, for an efficient degradation process (Figure 2) [26].

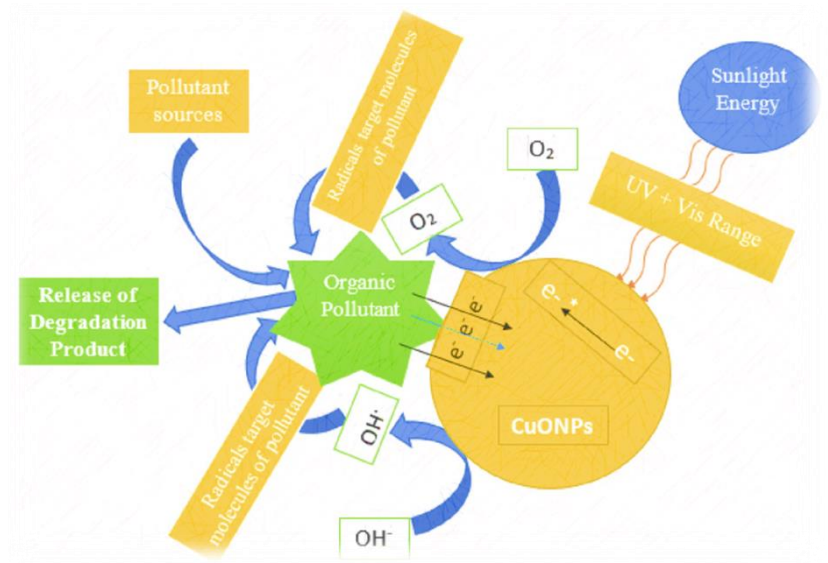

Figure 2. Scheme of pollutants degradation using the CuONPs. 


\subsection{Removal of Heavy Metals}

Heavy metal (HM) removal is dependent on the type, size, and morphology of metal oxide-based materials. Reduction, oxidation, and adsorption are the three fundamental ways in which the metal oxide-based materials work in remediation of heavy metals. A reaction between the heavy metals usually takes place during the adsorption process. This leads to the formation of inner-sphere complexes [27]. The mechanisms of HM removal by adsorption is shown below:

$$
\begin{aligned}
& \text { Surface- } \mathrm{OH}+\mathrm{H}^{+} \rightleftharpoons \text { Surface- } \mathrm{OH}_{2}^{+} \\
& \text {Surface- } \mathrm{OH} \rightleftharpoons \text { Surface- }-\mathrm{O}^{-}+\mathrm{H}^{+} \\
& \text {Surface-OH }+\mathrm{M}^{\mathrm{x}+} \rightarrow \text { Surface-O- } \mathrm{M}^{\mathrm{x}-1}+\mathrm{H}^{+} \\
& \text {2Surface- } \mathrm{OH}+\mathrm{M}^{\mathrm{x}+} \rightarrow(\text { Surface-O})_{2}-\mathrm{M}^{\mathrm{x}-1}+\mathrm{H}^{+} \\
& \text {2Surface- } \mathrm{OH}+\mathrm{M}^{\mathrm{x}+} \rightarrow(\text { Surface-O})_{2}-\mathrm{M}^{\mathrm{x}-1} \\
& \text { Surface- } \mathrm{O}^{-}+\mathrm{M}\left(\mathrm{H}_{2} \mathrm{O}\right)_{n}{ }^{\mathrm{x}+} \rightarrow \text { Surface- }-\mathrm{O}^{-} \ldots \ldots . .\left(\mathrm{H}_{2} \mathrm{O}\right)_{\mathrm{n}} \mathrm{M}^{\mathrm{x}+} \\
& \text { Surface-OH }+\mathrm{LB}^{-} \rightarrow \text { Surface- } \mathrm{LB}+\mathrm{H}_{2} \mathrm{O} \\
& \text { Surface-LB }+\mathrm{M}^{\mathrm{x}+} \rightarrow \text { Surface-LB-M }{ }^{\mathrm{x}+1}
\end{aligned}
$$

The oxidation and reduction processes often accompany adsorption, but may also occur independently. Reduction occurs when the redox potential of the HMs is more positive than the conduction band energy level of the metal oxide. Oxidation results in the case where the oxidation potential of the HMs is less positive compared to the valence band energy. The light source and the type of metal oxide play a key role in deciding the pathway as demonstrated by ZnO NPs (Figure 3) [28].

(a)
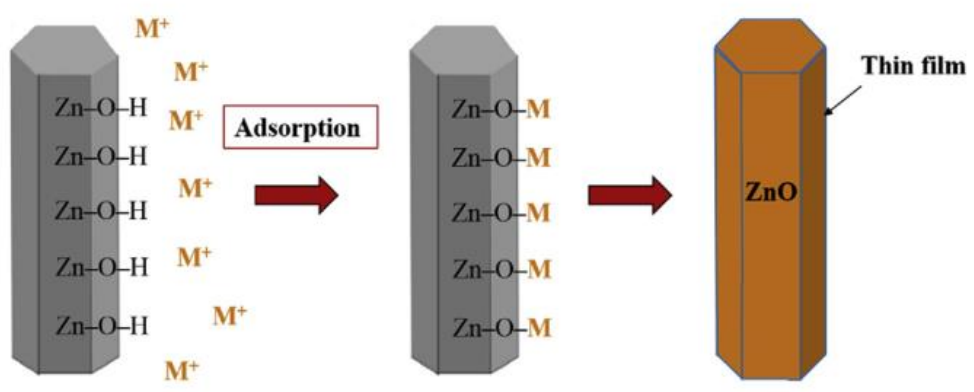

(b)
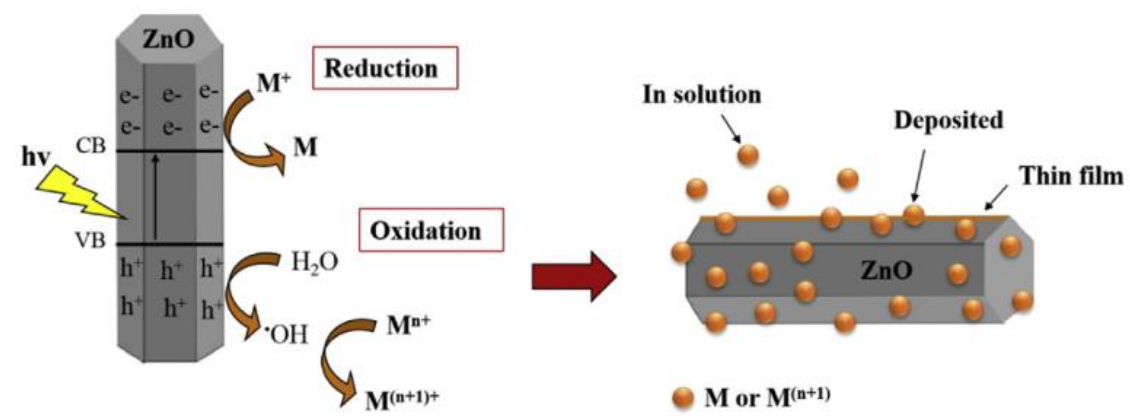

Figure 3. Removing heavy metal ions via (a) adsorption and (b) reduction/oxidation process using $\mathrm{ZnO}$ particles. 
Surface area is also an important factor in the mechanism of heavy metal adsorption by metal oxides. From the viewpoint of environmental friendliness, these oxides are suitable since these do not cause secondary pollution [29-31].

\subsubsection{Decarbonization}

Carbon dioxide reduction is an important process due to the environmental effect that it has. Fortunately, sunlight driven breakdown of $\mathrm{CO}_{2}$ could be also a cost-effective, readily achievable and benign method if the right kind of catalysts is designed. The techniques utilized to achieve this desired goal include optimizing the crystal structures and engineering the band gaps of metal-based photocatalysts. Perovskite, niobates, and ferrite materials, being among the notable metal oxides, have been widely used with these intentions for quite some time now [32]. These catalyze the carbon dioxide reduction in four steps as illustrated below (Figure 4):

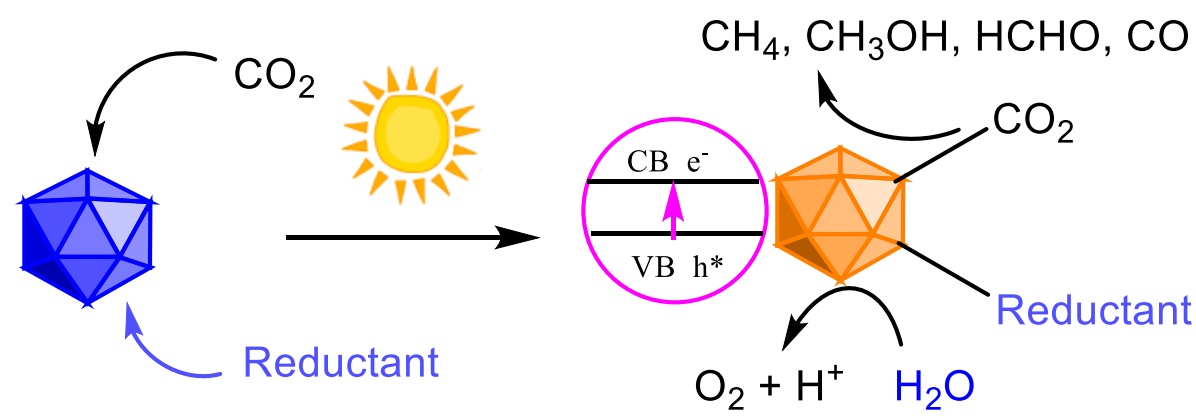

Figure 4. Photoreduction of carbon dioxide on metal oxide catalyst surfaces in the presence of sunlight and water.

a. Adsorption of reductant and $\mathrm{CO}_{2}$ onto the metal oxide catalyst surface;

b. Adsorption of sunlight on the perovskite leading to electron-hole separation;

c. Transfer of photogenerated charges to the surface and reaction with adsorbed $\mathrm{CO}_{2}$ and water;

d. Desorption of products.

A good reducing agent can enhance the efficiency of the valence band, considering its maximum is less than the reduction potential of water, which is a must for this type of process.

Apart from the environmental remediation, the photocatalytic reduction of $\mathrm{CO}_{2}$ is emerging as a green tool to produce chemicals and fuels by closing carbon cycle and realize zero carbon emission. Many chemicals and fuels for industrial applications, may be produced such as methanol $\left(\mathrm{CH}_{3} \mathrm{OH}\right)$, carbon monoxide $(\mathrm{CO})$, formic acid $(\mathrm{HCOOH})$, methane $\left(\mathrm{CH}_{4}\right)$, etc. These highly valuable products could be stored and manipulated more easily than $\mathrm{H}_{2}$ under ambient condition.

Apart form CaO-base solid sorbents for carbon capture and storage [33,34], perovskite-based sodium tantalate nanocubes ( $\mathrm{Vo}-\mathrm{NaTaON}$ ) [35], perovskite titanates [22], nanostructured $\mathrm{NaNbO}_{3}$ [36], $\mathrm{TiO}_{2}$ [37], $\mathrm{WO}_{3}, \mathrm{ZnO}, \mathrm{ZrO}_{2}, \mathrm{MgO}, \mathrm{Ga}_{2} \mathrm{O}_{3}$ and $\mathrm{Al}_{2} \mathrm{O}_{3}$, have been investigated for $\mathrm{CO}_{2}$ phtocatalytic reduction under $\mathrm{Uv} / \mathrm{Vis}$ light [38]. Among the various efficient and stable semiconductor photocatalysts for the production of renewable hydrocarbon fuels, layered double hydroxides (LDHs) have attracted recently great attention due to their high sorption capacity for $\mathrm{CO}_{2}$ in the layered space and the tunable semiconductor properties due to the metal cations chosen [39].

\subsubsection{Hydrogen Evolution}

Metal oxide catalyzed PEC water splitting occurs primarily in three steps (Figure 5) [40-43]:

a. Electron-hole pair generation by absorption of light;

b. Electron-hole pair separation and migration of these charge carriers to the surface of the photoelectrodes;

c. Splitting of water by the charge carriers on the surface of photocatalyst. 


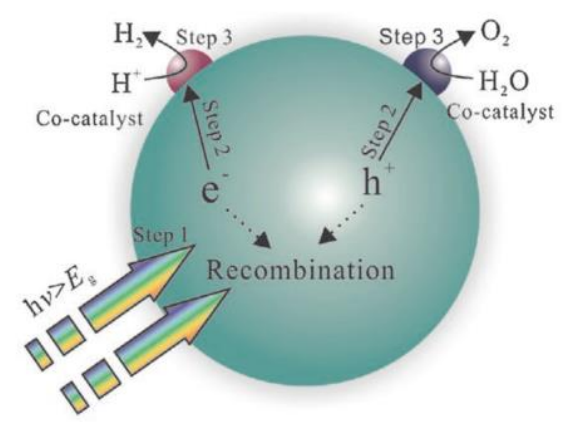

Figure 5. The three typical steps of photoelectrochemical (PEC) water splitting.

Since the pioneering work from Fuijima and Honda in 1972 [14] on solar water splitting from $\mathrm{TiO}_{2}$ elecrodes, several semiconductors and metal oxide semiconductors have been widely investigated as photocatalysts and photoelectrodes for PEC water splitting. Semiconductors from the group II-VI and III-V have a suitable band gap; however, due to their low absorption of solar radiation, their high electron-hole pairs recombination and low corrosion resistance, they do not show sufficiently high solar-to-hydrogen (STH) conversion efficiencies. Meanwhile, metal oxides seem to be more promising materials for application in solar-driven water splitting and $\mathrm{H}_{2}$ generation [44]. Despite all the efforts, there is still no commercial PEC device effectively producing solar hydrogen, mainly due to low STH conversion efficiency and low long-term stability due to chemical dissolution, electrochemical corrosion, and photocorrosion. The principal characteristics needed for a semiconductor or metal oxide semiconductor for PEC water splitting are (i) high visible absorption; (ii) long-term stability in aqueous environment; (iii) low kinetic overpotential for reduction/oxidation reactions, (iv) a good match of bandgap with the spectrum of the incident radiation; (v) suitable band edge positions to catalyze water reduction and oxidation; (vi) efficient charge conduction; (vii) low costs (abundance in quantity) [45].

Generally, metal oxides exhibit a large band gap, thus making them inefficient in absorbing the visible light photons which form the major portion of sunligh spectrum. Howevers, processing methods, doping and band gap engineering have been optimized to allow for the efficient use of solar energy. Metal oxide semiconductors have the advantage of being inexpensive, easy to manufacture, and are stable in aqueous environments. Among the metal oxides semiconductors n-type $\mathrm{WO}_{3}$, $\mathrm{BiVO}_{4}, \alpha-\mathrm{Fe}_{2} \mathrm{O}_{3}, \mathrm{ZnO}, \mathrm{TiO}_{2}$ and p-type $\mathrm{Cu}_{2} \mathrm{O}$ are the most widely investigated as electrodes and photoelectrodes [42-49]. They can be syntesized with different morphologies and nanostructures such as nanowires, nanorods, nanofibers, etc., and their catalytic activity can be enhanced by addition of dopants. Moreover, heterojunctions obtained combining different metal oxides may significantly enhance the separation of photogenerated electron-hole pairs [50]. To date, the highest reported efficiencies (18-19\%) have been obtained with hybrid arrangements involving the use of multiple bandgap structures [51]. The above mentioned metal oxides generally posses higher theoretical maximum STH conversion efficiencies if compared to $\mathrm{TiO}_{2}(1.3 \%$ and $2.2 \%$ for anatase and rutile, respectively), but may suffer from several drawbacks.

The theoretical maximum STH conversion efficiency for $\mathrm{WO}_{3}$ is $6 \%$ [42], higher than that of $\mathrm{TiO}_{2}$, and $\mathrm{WO}_{3}$ has the advantage of being chemically stable in acidic aqueous media, having a high hole diffusion length and a good electron mobility. However, $\mathrm{WO}_{3}{ }^{\prime} \mathrm{s}$ main drawback is the photocorrosion during the photocatalytic process due to the formation of peroxo-species [42,43]. $\mathrm{BiVO}_{4}$ has a large bandgap of $2.4 \mathrm{eV}$ and a theoretical maximum STH conversion of $9.1 \%$, but its main drawbacks are the poor mobility of photogenerated carriers and the slow oxygen kinetics which hinder its performance [42]. Photoelectrochemical performances of $\mathrm{BiVO}_{4}$ can be dramatically improved by prolonged exposure to AM 1.5 illumination in the open circuit (OC) configuration [52].

Hematite $\alpha-\mathrm{Fe}_{2} \mathrm{O}_{3}$ has several promising advantages such as its abundance, non-toxicity, and high photochemical stability in neutral and alkaline electrolyte solutions, that is of great importance for the commercial viability of the PEC systems [45]. It has got a narrow bandgap (in the range 1.9-2.2 eV), 
which maximizes the solar absorption leading to a theorerical maximum STH conversion of 14-17\%. However, the real STH does not exceed 5\% due to several drawbacks, i.e., the slow oxygen kinetics in water and the low carrier's mobility $[42,53]$.

Despite the very wide bandgap of 3.2-3.6 eV and its low STH conversion energy, ZnO also has been proposed as a photoanode for water splitting [54] due to its high carrier mobility and its low resistivity value, which allow for a high electron transfer efficiency. However, $\mathrm{ZnO}^{\prime}$ s main drawback is the poor chemical stability in aqueous electrolyte due to its amphoteric characteristic [42,54].

$\mathrm{Cu}_{2} \mathrm{O}$ has been used both as photoanode and photocathode $[44,45,48]$, but it seems more suitable as a p-type photocathode with a direct bandgap of 2.0-2.1 eV and a theoretical maximum STH of $18 \%$ [45]. Nevertheless, $\mathrm{Cu}_{2} \mathrm{O}$ shows a poor stability in water environments under solar irradiation and its activity in PEC water splitting systems is hindered by its low measured photocurrents [48].

All the mentioned metal oxides drawbacks can be limited by opportune synthesis processes, doping, co-doping, and nanostructuring, therefore enhancing and tailoring the materials' catalytic properties for PEC water splitting or environmental remediation, as described in the following paragraphs.

\subsection{Photocatalysis Using First-Row Transition Metal Oxide-Based Materials}

Catalytic reduction of multiple pollutants such as 4-nitrophenol, methylene blue, and rhodamine B was reported by utilizing copper oxide NPs immobilized on clinoptilolite surface. Rheum palmatum L. root extract was used as both a reducing and stabilizing agent. Several cycles of catalysis were sustained with sufficiently high catalytic activity [55]. Copper oxide nanoparticles synthesized from the bark extract of T. arjuna by microwave irradiation have been reported for their photocatalytic effect in the degradation of methylene blue. In addition to the adsorption of MB under light (63\%), the effectiveness of these $\mathrm{Cu}_{2} \mathrm{O}$ NPs was also seen in dark (55\%). The UV region was found to be most suitable for the complete degradation of methylene blue by these nanoparticles [56]. Copper oxide nanoparticles prepared from Zea mays L. dry husk extract were found to be $91 \%$ effective in the degradation of $\mathrm{MB}$ while the ability to degrade textile effluent was found to be $90 \%$. Both of the degradation processes were carried out under visible light [57]. The relatively high surface area of the $\mathrm{CuO}$ nanoparticles synthesized by a green procedure of chemical precipitation ensured their usability as photocatalysts for the degradation of Direct Red 81 (DR-81) and Coomassie Brilliant Blue R-250 (BBR-250) dyes. The activity was well established under the influence of inorganic ions and real water samples [58].

Apart from copper, iron also plays an important role in environmental remediation in form of its oxides. Two important oxides of iron, i.e., $\mathrm{Fe}_{2} \mathrm{O}_{3}$ and $\mathrm{Fe}_{3} \mathrm{O}_{4}$, have found important applications in this regard. The low bandgap of $2.2 \mathrm{eV}$ gives $\mathrm{Fe}_{2} \mathrm{O}_{3}$ a distinct advantage over other metal oxides. Moreover, another advantage is its cheap available price, and essentially its non-toxicity. Therefore, the use of iron oxide nanoparticles has increased over time. A suitable application of iron oxide nanoparticles was shown in the removal of the toxic dye Congo red which was degraded in the presence of $\mathrm{Fe}_{2} \mathrm{O}_{3}$ by the in situ-generated hydroperoxyl radicals [59]. The structure of $\mathrm{Fe}_{2} \mathrm{O}_{3}$ nanoparticles and the nature of its surface also influenced its catalytic activity. The concentration of the catalyst is also an important factor in the degradation of organic dyes as reported in the synthesis of porous $\alpha-\mathrm{Fe}_{2} \mathrm{O}_{3}$ nanorods which show optimised catalytic activity at a concentration of $20 \mathrm{mg}$ for every $100 \mathrm{~mL}$ [60]. The role of porosity in catalytic activity was further demonstrated by the hydrothermally synthesized $\mathrm{Fe}_{2} \mathrm{O}_{3}$ nanospheres which showed 2- and 12-fold enhancements compared to nanopowders and micron-sized powders of $\mathrm{Fe}_{2} \mathrm{O}_{3}$ [61]. Various shapes and sizes of nanoparticles impart properties suitable for catalytic degradation of dyes, some of which have been explored in detail. Employing the biphasic interfacial reaction route, flower-like $\alpha-\mathrm{Fe}_{2} \mathrm{O}_{3}$ nanospheres having large surface areas and porosity, were synthesized from the reactable ionic liquid ([Omim] $\mathrm{FeCl}_{4}$ ). These proved to be quite useful owing to the promotion of electron-hole transport. The recombination rate was also reported to be lowered by these nanospheres in the degradation of RhB in presence of hydrogen peroxide. Moreover, these also ensured improved hydroxide ion availability and proper channel for 
the interaction with dye molecule [62]. Interesting observations about the role of oxygen pressure were reported in the catalytic oxidation of azo dyes on the $\alpha-\mathrm{Fe}_{2} \mathrm{O}_{3}$ nanoparticle surface in an alkaline medium $(0.5 \mathrm{M} \mathrm{KOH})$ where the dye had a concentration of $20 \mathrm{mg} / \mathrm{L}$. The efficiency of the system varied linearly with the concentration of oxygen and resulted in the rapid discoloration of the dye within $10 \mathrm{~min}$ [63]. Coating the surface of nano-magnetic iron oxide (nano- $\mathrm{Fe}_{3} \mathrm{O}_{4}$ ) with nano-silica layer $\left[\right.$ nano- $\left.\mathrm{SiO}_{2}\right]$ resulted in the formation of the adsorbent nano- $\mathrm{Fe}_{3} \mathrm{O}_{4}$.

Nano- $\mathrm{SiO}_{2}$ could be used in a novel procedure for the removal of heavy metals via microwave-assisted solid-phase extraction. $\mathrm{Pb}$ (II), $\mathrm{Cu}(\mathrm{II}), \mathrm{Cd}(\mathrm{II})$ and $\mathrm{Hg}$ (II) uptake by the adsorbent took only about 5-20 s using this technique, which is a promising development for the quick removal of toxic heavy metals [64].

Zinc Oxide $(\mathrm{ZnO})$ nanoparticles are one of the most stable and efficient catalysts for degrading a wide range of pollutants. High oxidation ability is one of the characteristic features of $\mathrm{ZnO}$, the others being clean and inexhaustible reactions under solar irradiation and non-toxic nature. $\mathrm{ZnO}$ nanorods prepared by solution-based methods displayed photocatalytic degradation of Methyl Orange under solar irradiation [65]. Synthesis of ZnO-based materials from cork was developed as a sustainable, multi-function biomorphic system for environmental remediation. This graphite-containing composite material was prepared by infiltration of aerosol of solutions containing zinc ions into the pyrolysed cork. The performance of the $\mathrm{ZnO}$-cork material against the photodegradation was recorded in presence ofscavengers. The role of ${ }^{\circ} \mathrm{OH}$ radical was estimated to be crucial since the photocatalytic activity remained unaffected after the second cycle, although the adsorption efficiency decreased from 50\% to 30\% [66]. Zinc acetate and oxalic acid were used as the starting materials in various composite ratios by Chen et al. to obtain $\mathrm{ZnO}$ nanoparticles via the sol-gel method. All the variants showed good photocatalytic activity while being environmentally benign. $\mathrm{MO}, \mathrm{CR}$, and DB38 were the dyes that could be effectively degraded using these ZnO NPs [67]. Through a similar process, $\mathrm{ZnO}$ nanoparticles synthesized by the PEG sol-gel method were explored as photocatalysts in the degradation of Rhodamine B, methylene blue, and acridine orange in aqueous medium under solar light. $\mathrm{MB}$ and $\mathrm{AO}$ degradation reached nearly 100\% in 25 and $50 \mathrm{~min}$, respectively, but RB degradation could not be achieved with $\mathrm{ZnO}$ NPs. $\mathrm{TiO}_{2}$ NPs were, however, found useful for this purpose by displaying complete degradation of RB in $30 \mathrm{~min}$ [68].

Titanium dioxide is one of the most versatile oxides, which in thin film form or nanostructured electrode has utility in various fields and environmental applications.

A comparison between rutile and anatase nanocrystalline $\mathrm{TiO}_{2}$ showed that the mesoporous structure of the latter helped in achieving a better photocatalytic activity against Acetophenone, Nitrobenzene, MB, and Malachite green [69].

Commercial applicability of titanium dioxide nanoparticles as photocatalysts for environmental remediation has been achieved quite well among which, Degussa P-25, UV100, PC500, and $\mathrm{TiO}_{2}$-Tytanpol A11 are notable. Among these, P-25 was reported as the most suitable for the degradation of dyes of various types, namely, gentian violet, chromotrope $2 \mathrm{~B}$, amido black 10B, MB, Yellow 81, Reactive Violet 1, Red 198, Acid Black 1 and Acid Blue 7. The large surface area of P-25 and the slow recombination of the electron-hole pair have been identified as the two major factors behind the success of P-25 as a commercial photocatalyst [70].

Removal of methyl orange from the aqueous medium was achieved by 5-sulfosalicylic acid-surface modified $\mathrm{TiO}_{2}\left(\left(5-\mathrm{SA}-\mathrm{TiO}_{2}\right)\right.$. Following a pseudo-second-order kinetic model $(\mathrm{R} 2>0.99)$, wherein an increase of efficiency from $51 \%$ to $82.6 \%$ was observed as the concentration of $5-\mathrm{SA}-\mathrm{TiO}_{2}$ was increased from 0.02 to $0.08 \mathrm{~g} / \mathrm{L}$ [41]. Daylight-induced 100\% degradation of Rose Bengal dye was achieved by carbon, nitrogen and sulphur-doped $\mathrm{TiO}_{2}\left(\mathrm{CNS}-\mathrm{TiO}_{2}\right)$ nanoparticles in only $60 \mathrm{~min}$. However, the $\mathrm{pH}$ had to be maintained at 6 , at which the catalytic loading of $0.1 \mathrm{~g} / 100 \mathrm{~mL}$ could effectively work on 20 ppm of dye concentration [71].

$\mathrm{TiO}_{2}$ nanoparticles synthesized from Jatropha curcas L. via a green and eco-friendly procedure resulted in multiple benefits namely removal of chemical oxygen demand and chromium ions from 
tannery wastewater. Removal rates of $82.2 \%$ and $76.48 \%$, respectively, for COD and Cr could be achieved by the anatase phase of these spherical $\mathrm{TiO}_{2}$ nanoparticles under solar irradiation [72] . A comparative study on the performance of nanozigzag, nanohelics, and nanorod structures of $\mathrm{TiO}_{2}$ against methylene blue, methylene violet, and methyl orange revealed that MB and MV could be easily degraded up to $97 \%$ but $\mathrm{MO}$ degradation was only up to $80 \%$ since its anionic nature allows minimal electrostatic interaction with the nanoparticles. The best performance for degradation of all the dyes was shown by the zigzag morphology owing to the large total surface area which allows creation of photo-induced electron-hole pairs [73]. Apart from organic dyes, other environmentally harmful chemical species also need removal from water bodies. In one such case, carbonated mesoporous $\mathrm{TiO}_{2}$ has been reported as a potent material for the adsorption and removal of toxic strontium ions. $4 \mathrm{C}-\mathrm{TiO}_{2}$ ( $4 \%$ carbonate) was the most efficient variant with an adsorption capacity of $204.4 \mathrm{mg} / \mathrm{g}$ [74].

\subsection{Photocatalysis Using Second and Third Row Transition Metal Oxide-Based Materials}

A host of photocatalytic materials have been designed utilizing the metal oxides of second and third row transition metals. Tungsten oxide $\left(\mathrm{WO}_{3}\right)$ is a cheaply available material with a favorable response toward solar radiation and a narrow bandgap ranging from 2.4 to $2.8 \mathrm{eV}$. The only drawback of pure $\mathrm{WO}_{3}$ is the fast recombination of electron-hole pairs. To overcome this hurdle, many researchers have focused on developing various nanostructured $\mathrm{WO}_{3}$ materials. Hydrothermally synthesized hierarchical nanosheets enabled $\mathrm{WO}_{3}$ with tremendous photocatalytic activity against $\mathrm{MB}$, Eosin Red, and Congo Red. The wastewater treatment capability of these nanosheets was replicated by $\mathrm{WO}_{3}$ nanorods fabricated by a similar hydrothermal method. Both the system displayed excellent degradation results under visible light $[75,76]$. Flower-like $\mathrm{WO}_{3}$ arranged in a hierarchical fashion and capable of decolorizing RhB in aqueous solution under visible light, were prepared by a simple hydrothermal method. This flower-like porous structural pattern gave these $\mathrm{WO}_{3} \mathrm{NPs}$ a distinct advantage over the non-hierarchical analogs. The reason assigned to this noticeable advantage was the presence of specific hierarchical pores that facilitated the transport of the reactants and light. The potential of the hierarchical NPs was further established by the nearly unaltered degradation rates of $\mathrm{RhB}$ even after five cycles. [77]. Among the diverse $\mathrm{WO}_{3}$ nanostructured materials with varying morphologies as prepared by Adhikari et al., the rod-shaped ones displayed superior performance in the photocatalytic degradation of $\mathrm{RhB}$ compared to $\mathrm{WO}_{3}$ nanoparticles [78]. MB degradation using hierarchical double-shell Tungsten trioxide $\left(\mathrm{HDS}-\mathrm{WO}_{3}\right)$ microspheres proved to be significantly advantageous over commercially available $\mathrm{WO}_{3}$, and realized a photocatalytic activity of $84.9 \%$ under visible light. The high efficiency was ascribed to the large total surface area facilitated by the hierarchical structure [79]. The relevance of the percentage of oxygen vacancies in tungsten oxide NPs in the context of their morphologies and the resultant photocatalytic activities was demonstrated by Guo et al. $\mathrm{WO}_{2.72}$ nanowires and urchin-like $\mathrm{WO}_{2.72}$ nanostructures were both derived through the solvothermal method, but the former displayed a greater photocatalytic activity against RhB, $\mathrm{MB}$ and MO. The influence of the wire-like morphology was found to be the cause for photoelectron transfer than the greater number of oxygen vacancies present in the 3D network of urchin-like $\mathrm{WO}_{2.72}$ nanostructures. Both of these however, were much ahead of the commercially available nanostructured tungsten oxide in terms of degrading the pollutants under ultraviolet irradiation [80].

\subsection{Photocatalysis Using Mixed Metal/Metal-Oxide Systems}

Cost of raw materials, bandgap, nanostructure, and adsorption are some key factors that determine the suitability of metal oxides as photocatalysts for organic pollutant degradation. Pure metal oxides often fall short in one or more of these parameters. Therefore, a lot of research has been done on the possibility of fabricating multi-metal systems that incorporate metal-oxide nanostructures.

Electron-hole separation is the key to effective photocatalysis demonstrated by metal oxides. This property can be further tuned by adding other metal compounds in various proportions as demonstrated by Salari and Kohantorabi. They synthesized novel $\alpha-\mathrm{MnO}_{2}$ nanorod/silver iodide $\mathrm{p}-\mathrm{n}$ 
junction NCs, which were found suitable for enhanced absorption of visible light, and separation of electron-hole pairs. As a result, Acid blue 92 (AB92) degradation was achieved with 100\% efficiency in only $40 \mathrm{~min}$ (Figure 6).

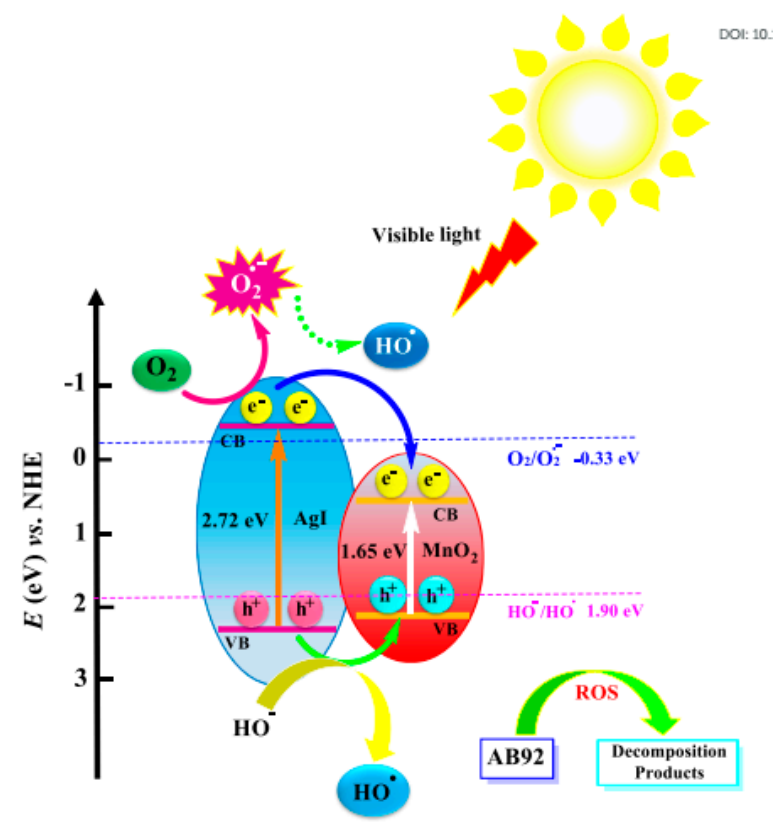

Figure 6. Mechanism for the separation electron/hole pairs in the $\alpha-\mathrm{MnO}_{2} / \mathrm{AgI}$ photocatalyst.

The visible light response was achieved through the combination of band gaps $(\approx 1.4 \mathrm{eV}$ for $\mathrm{Ag}_{2} \mathrm{~S}$ and $\approx 3.3 \mathrm{eV}$ for $\mathrm{ZnO}$ ) which facilitated photocatalysis. Positive piezo charges, generated due to the strain within the fabricated hybrid, allowed the effective lowering of barrier height which promoted charge transport across the whole heterostructure [81]. Various metals, namely, Ag, Ni and Fe, were utilized to dope $\mathrm{ZnO}$ nanostructures to achieve optimal band gaps. Turkyilmaz et al. employed this process to achieve resultant nanostructures having varied degrees of photocatalytic ability for the degradation of tartrazine. The synergistic effect shown by $\mathrm{Ni}$ and Ag made the respective NPs more suitable while those resulting from the doping by Fe and Mn showed minimal activity. Charge separation was identified as the cause of the photocatalysis, and the maximum degradation (98.2\%) of tartrazine was achieved with Ni/ZnO NPs in $60 \mathrm{~min}$ [82]. In a novel attempt, Chang et al. synthesized $\mathrm{CuO} / \mathrm{In}_{2} \mathrm{~S}_{3} / \mathrm{ZnO}$ heterostructures in a multi-step process. Morphological analysis showed 1D CuO nanowire core covered by an intermediate layer of $\mathrm{In}_{2} \mathrm{~S}_{3}$ nanostructures which were in turn covered by sheaths of $\mathrm{ZnO}$ nanorods. Photocatalytic activity at the resultant ternary heterostructure tested for the degradation of RhB under low UV light irradiation showed excellent results in comparison to one-component $\mathrm{CuO}$ nanowires and two-component $\mathrm{CuO} / \mathrm{In}_{2} \mathrm{~S}_{3}$ arrays even after five cycles [83]. There appears to be a positive association between thermal annealing of the precursor $\mathrm{ZnS}$ (en) 0.5 under air, and the formation of porous $\mathrm{ZnS}, \mathrm{ZnO}$ and $\mathrm{ZnS}-\mathrm{ZnO}$ nanosheets. The ZnS-ZnO NSs prepared by this technique exhibit excellent performance in degrading RhB under a $250 \mathrm{~W}$ high-pressure $\mathrm{Hg}$ lamp (365 nm) owing to the largest surface area among the three types of NSs. [84]. Sensitization of zinc oxide nanoparticles by CuInZn $n_{x} S_{2+x}$ (ZCIS) quantum dots (QDs) yielded composites that displayed great photocatalytic activity for the degradation of orange II under the simulation of solar light $\left(5 \mathrm{~mW} / \mathrm{cm}^{2}\right)$. As a result of the heterojunction between $\mathrm{ZnO}$ and ZCIS QDs, not only the extension of light absorption range was possible, but also the electron-hole recombination was decreased significantly. Therefore, these nanocomposites executed more than $95 \%$ degradation of orange II in about $180 \mathrm{~min}$. Moreover, the composites produced greater number of singlet oxygen along with hydrogen peroxide which proved to be pivotal in the degradation process [85]. Alternative sources of energy, namely, solar and mechanical, could be used by the CuS/ZnO nanowires operating 
with high piezo-photocatalytic efficiency for the degradation of organic pollutants. The process of preparing these $\mathrm{CuS} / \mathrm{ZnO}$ heterostructured nanowire (NWs) arrays utilized a two-step approach wherein a wet-chemical method was employed to align these NWs compactly onto a stainless steel mesh. The large surface area of these composite NWs expedites light harvesting and an equally interesting observation was that the photocatalytic activity was enhanced even further by ultrasonic waves, owing to the synchronization of the piezoelectric field of $\mathrm{ZnO}$ with the electric field of the heterostructure [86]. Nanospheres formed out of four different combinations of AuAg bimetallic particles attached to the surface of $\mathrm{ZnO}$, afforded photolytic production of hydrogen gas in addition to excellent photolcatalytic removal of RhB. The role of Au in this system is higher as compared to that of Ag. While the former due to its excess concentration forms a blue-shifted plasmon, the latter forms a red-shifted one since it is present only as a thin layer. The percentage of each influences the overall oxygen vacancies in $\mathrm{ZnO}$ and thereby influences the photodegradation process [3].

Hierarchical synthesis of $\mathrm{Ag} / \mathrm{AgClWO}$ nanoplates was reported by Chen et al. who found these to be better than $\mathrm{Ag} / \mathrm{AgCl}, \mathrm{AgCl}, \mathrm{AgClWO}_{3}$ and $\mathrm{P}-25$ for the photocatalytic degradation of $\mathrm{RhB}$ in aqueous medium [60]. Combining the techniques of photochemical reduction and deposition, Yuan et al. prepared Z-scheme $\mathrm{Ag}_{2} \mathrm{CO}_{3} / \mathrm{Ag} / \mathrm{WO}_{3}$ composites that were found to be extremely effective in degrading RhB, MO, ciprofloxacin (CIP) and tetracycline hydrochloride (TC) via photocatalysis. A surface plasmon resonance (SPR) effect was considered to be the reason behind the separation of photogenerated charge carriers by absorbing visible light over a large range of wavelengths. The $\mathrm{z}$ scheme was also considered as a major reason behind the variety of photocatalytic activity for which the composites were far superior compared to both $\mathrm{Ag}_{2} \mathrm{CO}_{3} \mathrm{NRs}$ and $\mathrm{WO}_{3} \mathrm{NPs}_{\text {[4]. }}$.

Ultrasound-assisted precipitation was the technique lying at the heart of Ag6Si2O7/WO3 photocatalyst synthesis. Molar ratios of each of the components played a key role in the photocatalytic performance of these composites for the degradation of $\mathrm{MB}, \mathrm{RhB}, \mathrm{MO}$ and 2,4-dichlorophenol under visible light. A 1:1 combination of $\mathrm{Ag}_{6} \mathrm{Si}_{2} \mathrm{O}_{7}$ and $\mathrm{WO}_{3}$ exhibited 97.4\% degradation of $\mathrm{MB}$ in only $30 \mathrm{~min}$, higher than both $\mathrm{Ag}_{6} \mathrm{Si}_{2} \mathrm{O}_{7}(87.3 \%)$ and $\mathrm{WO}_{3}(14.0 \%)$, when used separately. Electron-hole pair separation was the primary cause behind the activity shown by this heterojunction material in aqueous medium [87].

Coating the surface of iron oxide nanoparticles with various substances or doping these with other metals plays an important role in their stability enhancement. In this context, the work of Liu et al. showed promise in environmental remediation. $\mathrm{Hg}(\mathrm{II}), \mathrm{Pb}(\mathrm{II}), \mathrm{Cd}(\mathrm{II})$, and $\mathrm{Cu}(\mathrm{II})$, all known as quite toxic to aquatic life, were removed efficiently by the $\mathrm{Fe}_{3} \mathrm{O}_{4} \mathrm{NPs}$ coated with humic acid $\left(\mathrm{Fe}_{3} \mathrm{O}_{4} / \mathrm{HA}\right)$. While the sorption of heavy metals was possible within $15 \mathrm{~min}$ by $\mathrm{Fe}_{3} \mathrm{O}_{4} / \mathrm{HA}$, it was quite stable in a range of aquatic systems like tap water, solutions of different $\mathrm{pH}(0.1 \mathrm{M} \mathrm{HCl}-2 \mathrm{M} \mathrm{NaOH})$, natural waters with insignificant leaching. Removal of $\mathrm{Hg}$ (II) and $\mathrm{Pb}$ (II) was achieved up to $99 \%$, while $95 \%$ of $\mathrm{Cu}(\mathrm{II})$ and $\mathrm{Cd}$ (II) could be removed from natural and tap waters [63]. Spinel structure of ferrites offers a large surface area for activity which is the focus of researchers for the removal of environmental contaminants. In keeping with this idea, Esmat et al. designed Cobalt ferrite nanoparticles (CF) and the nanocomposite $\mathrm{CF} / \mathrm{G}$ derived from these and alginate $(\mathrm{G})$. In addition, they also developed titanate nanoparticles and the corresponding alginate nanocomposite T/G. At a pH of 6.5 and contact time of $2 \mathrm{~h}$, these NPs and NCs displayed removal of $\mathrm{Cu}^{2+}, \mathrm{Fe}^{3+}$ and $\mathrm{As}^{3+}$ ions at efficiencies of more than $98 \%$, from water [88]. Additionally, perovskites can play a crucial role in removal of heavy metals as demonstrated by Rao et al. in their investigation on $\mathrm{LaFeO}_{3}$ ferroelectric nanostructures. These perovskite nanomaterials having sizes less than $50 \mathrm{~nm}$, were synthesized by sol-gel method from oxalic, citric and succinic acids and the last one showed efficient removal (86.34\%) of $\mathrm{Cd}$ (II) ions from water $[89,90]$. Magnetite-kaolinite nanocomposite was prepared from $\mathrm{FeCl}_{3} \cdot 6 \mathrm{H}_{2} \mathrm{O}, \mathrm{FeCl}_{2} \cdot 4 \mathrm{H}_{2} \mathrm{O}$ and kaolinite via chemical co-precipitation method. Due to the supermagnetism displayed by this nanocomposite, toxic heavy metals could be separated from aqueous media without the need of any assisting technique. $\mathrm{Cu}^{2+}$ was the most easily removed ion, followed by other heavy metals in the 
order $\mathrm{Pb}^{2+}>\mathrm{Cr}(\mathrm{VI})>\mathrm{Cd}^{2+}>\mathrm{Ni}^{2+}$. The role of functional groups $\mathrm{Si}-\mathrm{O}-\mathrm{Si}$, and $\mathrm{Si}-\mathrm{O}-\mathrm{Al}$ originating from kaolinite was found to be important in the binding preferences [91].

Decoration of Ferrosoferric oxide $\left(\mathrm{Fe}_{3} \mathrm{O}_{4}\right)$ by transition metal provided the scope for photocatalytic removal of Carbol Fuchsin, one of the major industrial pollutants harmful to living organisms, especially plant life. $\mathrm{Co}^{2+}$ and $\mathrm{Ni}^{2+}$ were used as dopants to synthesize the doped $\mathrm{Fe}_{3} \mathrm{O}_{4} \mathrm{NPs}$ via co-precipitation under sonication. The removal of Carbol Fuchsin was enhanced by doping which caused lowering of the bandgap in ferrosoferric oxide. About $25 \mathrm{~min}$ after the initiation of photodegradation, the dye was degraded to a major extent and after $90 \mathrm{~min}$, the maximum removal of $97 \%$ was realized [92]. Doping of cobalt oxide NPs by $\mathrm{Fe}^{2+}$ and $\mathrm{Ni}^{2+}$ ions yielded modified $\mathrm{Co}_{3} \mathrm{O}_{4}$ nanocatalysts, having a particle size of $200 \mathrm{~nm}$. The photocatalytic degradation of Eosin Blue (EB) using this nanocatalyst was studied under mercury irradiation. Modification afforded more stability to the cobalt oxide NPs along with enhancing the degradation of EB to 95\% flowing a pseudo-first-order reaction kinetics. Enhancement of surface area was identified as one of the key reasons for the better photocatalytic activity of this $\mathrm{Fe}^{2+}, \mathrm{Ni}^{2+}$ - doped $\mathrm{Co}_{3} \mathrm{O}_{4}$ nanocatalyst [93].

A comparative study was done by Shojaei et al. on the performance of $\mathrm{WO}_{3} / \mathrm{TiO}_{2} / \mathrm{Fe}_{3} \mathrm{O}_{4}$ nanocomposites and $\mathrm{TiO}_{2}$, as well as $\mathrm{WO}_{3} / \mathrm{TiO}_{2}$ and $\mathrm{TiO}_{2} / \mathrm{Fe}_{3} \mathrm{O}_{4}$ as photocatalysts for the degradation of organic dyes. Direct blue 71 was efficiently removed ( $98 \%$ removal under visible light irradiation) from aqueous solution using the $5 \% \mathrm{WO}_{3} / \mathrm{TiO}_{2} / \mathrm{Fe}_{3} \mathrm{O}_{4}$ nanocomposite. Compared to $\mathrm{TiO}_{2}$, the nanocomposite could be used up to six times without any loss in catalytic activity and due to its magnetic properties, could be easily separated from the reaction medium by using an external magnet [94]. Combination of Bismuth oxybromide with $\mathrm{Fe}_{3} \mathrm{O}_{4}$ resulted in the formation of nano $\mathrm{Fe}_{3} \mathrm{O}_{4} / \mathrm{BiOBr}$ magnetic microspheres via solvothermal method. While its magnetic property made the separation from the reaction medium very easy, its stability ensured photocatalytic activity to be maintained after four successive runs. Based on these properties, the microspheres were found to be useful in degrading RhB up to $100 \%$ under visible light irradiation by following a pseudo-first-order reaction [86]. The higher rate of electron-hole recombination is a major problem in optimizing $\mathrm{TiO}_{2} \mathrm{NPs}$ for photocatalytic activity. A recent report by Tiruppathi et al. sought to solve this problem through the synthesis of $\mathrm{Ce}-\mathrm{TiO}_{2}$ nanocomposites via a one-step hydrothermal method by using titanium isopropoxide and cerium nitrate as the starting materials. The NCs were found to be efficient photocatalyst for the degradation of rose Bengal (RB) and acid red (AR) and sodium diclofenac [70]. Using solar light as the source of irradiation, noble-metal loaded $\mathrm{TiO}_{2} \mathrm{NPs}\left(\mathrm{M}-\mathrm{TiO}_{2}, \mathrm{M}=\mathrm{Ag}\right.$, $\mathrm{Au}$ and $\left.\mathrm{Pt}\right)$ were found to be very efficacious in removing the analgesic drug acetaminophen (AP) from aqueous solution. The comparison with pure titanium oxide NPs revealed that the noble-metal loaded modified NPs reduced the electron-hole recombination in addition to extending the visible light absorption capacity. Furthermore, the modified NPs showed dynamic role in the generation of $\mathrm{H}_{2} \mathrm{O}_{2},{ }^{\circ} \mathrm{OH}$ and ${ }^{\circ} \mathrm{OOH}$ which are known for their reactive nature in the photodegradation process. $\mathrm{Pt}-\mathrm{TiO}_{2}$ was found to be the best phtocatalyst among these modified $\mathrm{NPs}$ [95]. Bismuth sulfide $\left(\mathrm{Bi}_{2} \mathrm{~S}_{3}\right)$ semiconductor nanotubes were used to decorate $\mathrm{TiO}_{2}$ nanoparticles to obtain $\mathrm{Bi}_{2} \mathrm{~S}_{3}-\mathrm{TiO}_{2}$ heterostructures via solvothermal technique. Large surface area and good optical properties presented this system as a potential photocatalyst under natural solar light. Amaranth dye was degraded under solar light in presence of $\mathrm{Bi}_{2} \mathrm{~S}_{3}-\mathrm{TiO}_{2}$ up to $98 \%$ in $90 \mathrm{~min}$ [96].

In a two-step process, electrochemical growth of $\mathrm{ZnO}$ nuclei on fluorine-doped tin oxide surface was followed by electrodeposition of $\mathrm{Ag}$ on $\mathrm{ZnO}$. The resultant $\mathrm{ZnO}$-Ag nanorod composite photoelectrodes displayed almost four-fold enhancement in photo-electrocatalytic degradation of MO compared to pure $\mathrm{ZnO}$ as a consequence of synergistic effect between the $\mathrm{ZnO}$ and $\mathrm{Ag}$ particles. As the charge carriers were stabilized by the Schottky barrier formed at the $\mathrm{ZnO}-\mathrm{Ag}$ interface, the Ag metal particles acted as sinks for those along with being the catalytic centers [89-94].

The deep removal of sulfur from liquid fuels is an extremely important issue to deal with environmental pollution by sulfur compounds $[95,96]$. In this context, photocatalytic oxidative desulfurization of model-fuel (dibenzothiophene, DBT in n-hexane) and real naphtha was reported by Ammar et al. who used dual-functional $\mathrm{CuO}-\mathrm{Fe}_{3} \mathrm{O}_{4}$ magnetic nanocomposites (MNCs) for the 
purpose. These nanocomposites were found to be effective in removing 95.2\% of DBT after $120 \mathrm{~min}$ under a catalyst dose of $10 \mathrm{~g} / \mathrm{L}$. From the naptha fuel, $93 \%$ of sulfur conversion could be achieved in $240 \min [97-99]$.

\section{Summary and Prospects}

As one of the most sought-after fields of research due to the scope of structural and functional variation that can be produced, metal oxides continue to be explored for the environmental remediation, for solving the energy crisis and for decarbonization.

However, the challenges provided by the actual implementation need to be solved effectively. Finding organic ligands, metal oxides, solvents, dopants and other chemicals with low cost and the least environmental impact remains a challenge. At the same time, the most positive aspects of metal oxide-based materials remain the easy tuning of their bandgaps for photocatalytic purposes. As discussed in this paper, the degradation of dyes, antibiotics, and pesticides do show much promise toward remediation of wastewaters, as does the photoreduction of $\mathrm{CO}_{2}$. Overall, this field of research shows the potential for growth in a future tuned toward smart materials for energy and environmental sustainability.

The present article discusses the structural features and photocatalytic applications of a variety of metal oxide-based materials employing $\mathrm{TiO}_{2}, \mathrm{WO}_{3}, \mathrm{ZnO}, \mathrm{ZrO}_{2}, \mathrm{MgO}, \mathrm{Ga}_{2} \mathrm{O}_{3}, \mathrm{Al}_{2} \mathrm{O}_{3}, \mathrm{Fe}_{3} \mathrm{O}_{4}$, etc. Several morphologies and nanostructures, composites, hybrid structures, functionalizing metals, have been analyzed and the scalability from laboratory to real applications discussed. These oxides play a key role in decarbonization strategies and have become an important factor in industrial expansion, along with the invention of new catalytic methods for carrying out non-thermal reactions, energy storage methods and environmental remediation through the removal or breakdown of harmful chemicals released during manufacturing processes. The scalabalility from laboratory to industrial scale is one of the major aspects that needs to be looked at, when considering the metal oxide-based materials. Large-scale production is necessary in order to fulfill the goals of environmental remediation, decarbonization and energy sustainability. The points that need to be considered while formulating metal oxide-based materials as photocatalysts for commercial purposes can be summarized as follow:

a. Availability and cost of precursor metals, their oxides, and other auxiliary materials for their synthesis;

b. Toxicity of the metals/metal oxides, auxiliary materials and pollution caused while producing these;

c. Energy-efficient batch production;

d. High specific surface area and well-tuned bandgap for efficient adsorption and catalytic activity;

e. Ability to work under sunlight or other forms of visible light;

f. Possibility of addressing multiple environmental pollutants and/or energy storage and conversion strategies.

g. Easy recovery and recyclability of the photocatalysts.

However, many of the metal oxide systems reported in the literature suffer from a high economic cost of manufacturing. Out of a plethora of metal oxide-based nanoparticles reported thus far, $\mathrm{ZnO}$ and $\mathrm{TiO}_{2}$ have found their way into commercial applications, while iron oxide-based materials are also being explored owing to their easy magnetic separation [100-106].

Concerning the production of renewable energy, still some drawbacks need to be overcome. For instance, all the investigated metal oxides photoelectrodes suffer from low STH conversion efficiency and low long-term stability due to chemical dissolution, electrochemical corrosion, and photocorrosion, and $\mathrm{CO}_{2}$-derived fuels are actually not competitive to fuel oils due to their high economic costs.

Author Contributions: Conceptualization, M.S.S.D.; methodology, A.B.; validation, T.S.; formal analysis, A.B.; investigation, D.S.; resources, M.K. and M.S.S.D.; data curation, M.S.S.D. and A.B.; writing一original draft preparation, M.S.S.D.; writing—review and editing, A.M., D.S. and M.L.G.; visualization, M.K.; supervision, A.M.; 
project administration, D.S.; funding acquisition, A.M., D.S. All authors have read and agreed to the published version of the manuscript.

Funding: This research received no external funding.

Conflicts of Interest: The authors declare no conflict of interest.

\section{References}

1. Grilli, M.L. Metal Oxides. Metals 2020, 10, 820. [CrossRef]

2. Nunes, D.; Pimentel, A.; Santos, L.; Barquinha, P.; Pereira, L.; Fortunato, E.; Martins, R. Structural, optical, and electronic properties of metal oxide nanostructures. Met. Oxide Nanostruct. 2019, 59-102. [CrossRef]

3. Gautam, S.; Agrawal, H.; Thakur, M.; Akbari, A.; Sharda, H.; Kaur, R.; Amini, M. Metal oxides and metal organic frameworks for the photocatalytic degradation: A review. J. Environ. Chem. Eng. 2020, 8, 103726. [CrossRef]

4. D'Anna, F.; Grilli, M.L.; Petrucci, R.; Feroci, M. $\mathrm{WO}_{3}$ and Ionic Liquids: A Synergic Pair for Pollutant Gas Sensing and Desulfurization. Metals 2020, 10, 475. [CrossRef]

5. Pei, C.; Han, G.; Zhao, Y.; Zhao, H.; Liu, B.; Cheng, L.; Yang, H.; Liu, S. Superior adsorption performance for triphenylmethane dyes on 3D architectures assembled by $\mathrm{ZnO}$ nanosheets as thin as $\sim 1.5 \mathrm{~nm}$. J. Hazard. Mater. 2016, 318, 732-741. [CrossRef]

6. Zhan, X.Q.; Yu, X.Y.; Tsai, F.C.; Ma, N.; Liu, H.L.; Han, Y.; Xie, L.; Jiang, T.; Shi, D.; Xiong, Y. Magnetic MOF for AO7 Removal and Targeted Delivery. Crystals 2018, 8, 250. [CrossRef]

7. Fan, J.; Chen, D.; Li, N.; Xu, Q.; Li, H.; He, J.; Lu, J. Adsorption and biodegradation of dye in wastewater with $\mathrm{Fe}_{3} \mathrm{O}_{4} @ \mathrm{MIL}-100$ (Fe) core-shell bio-nanocomposites. Chemosphere 2018, 191, 315-323. [CrossRef] [PubMed]

8. Hadjltaief, H.B.; Ben Zina, M.; Galvez, M.E.; Da Costa, P. Photocatalytic degradation of methyl green dye in aqueous solution over natural clay-supported $\mathrm{ZnO}-\mathrm{TiO}_{2}$ catalysts. J. Photochem. Photobiol. A Chem. 2016, 315, 25-33. [CrossRef]

9. Yumashev, A.; Mikhaylov, A. Development of polymer film coatings with high adhesion to steel alloys and high wear resistance. Polym. Compos. 2020, 41, 2875-2880. [CrossRef]

10. Yumashev, A.V.; Ślusarczyk, B.; Kondrashev, S.; Mikhaylov, A. Global Indicators of Sustainable Development: Evaluation of the Influence of the Human Development Index on Consumption and Quality of Energy. Energies 2020, 13, 2768. [CrossRef]

11. Grilli, M.L.; Chevallier, L.; Di Vona, M.L.; Licoccia, S.; Di Bartolomeo, E. Planar electrochemical sensors based on YSZ with $\mathrm{WO}_{3}$ electrode prepared by different chemical routes. Sens. Actuators B Chem. 2005, 111, 91-95. [CrossRef]

12. Masetti, E.; Grilli, M.L.; Dautzenberg, G.; Macrelli, G.; Adamik, M. Analysis of the influence of the gas pressure during the deposition of electrochromic $\mathrm{WO}_{3}$ films by reactive r.f. sputtering of $\mathrm{W}$ and $\mathrm{WO}_{3}$ target. Sol. Energy Mater. Sol. Cells 1999, 56, 259-269. [CrossRef]

13. Grilli, M.L.; Kaabbuathong, N.; Dutta, A.; Di Bartolomeo, E.; Traversa, E. Electrochemical $\mathrm{NO}_{2}$ Sensors with $\mathrm{WO}_{3}$ Electrodes for High Temperature Applications. J. Ceram. Soc. Jpn. 2002, 110, 159-162. [CrossRef]

14. Fujishima, A.; Honda, K. Electrochemical Photolysis of Water at a Semiconductor Electrode. Nat. Cell Biol. 1972, 238, 37-38. [CrossRef] [PubMed]

15. Aydoğan, Ş.; Grilli, M.L.; Yilmaz, M.; Çaldiran, Z.; Kaçuş, H. A facile growth of spray based ZnO films and device performance investigation for Schottky diodes: Determination of interface state density distribution. J. Alloys Compd. 2017, 708, 55-66. [CrossRef]

16. Yilmaz, M.; Grilli, M.L.; Turgut, G. A Bibliometric Analysis of the Publications on In Doped ZnO to be a Guide for Future Studies. Metals 2020, 10, 598. [CrossRef]

17. Yilmaz, M.; Grilli, M.L. The modification of the characteristics of nanocrystalline $\mathrm{ZnO}$ thin films by variation of Ta doping content. Philos. Mag. 2016, 96, 2125-2142. [CrossRef]

18. USGS. National Minerals Information Center. 2020. Available online: https://www.usgs.gov/centers/nmic/ iron-oxide-pigments-statistics-and-information (accessed on 27 November 2020).

19. Tanaka, Y.; Utaka, T.; Kikuchi, R.; Sasaki, K.; Eguchi, K. CO removal from reformed fuel over $\mathrm{Cu} / \mathrm{ZnO} / \mathrm{Al}_{2} \mathrm{O}_{3}$ catalysts prepared by impregnation and coprecipitation methods. Appl. Catal. A Gen. 2003, 238, 11-18. [CrossRef] 
20. Koli, P.B.; Kapadnis, K.H.; Deshpande, U.G. Transition metal decorated Ferrosoferric oxide $\left(\mathrm{Fe}_{3} \mathrm{O}_{4}\right)$ : An expeditious catalyst for photodegradation of Carbol Fuchsin in environmental remediation. J. Environ. Chem. Eng. 2019, 7. [CrossRef]

21. Wen, Z.; Ke, J.; Xu, J.; Guo, S.; Zhang, Y.; Chen, R. One-step facile hydrothermal synthesis of flowerlike Ce/Fe bimetallic oxides for efficient $\mathrm{As}(\mathrm{V})$ and $\mathrm{Cr}(\mathrm{VI})$ remediation: Performance and mechanism. Chem. Eng. J. 2018, 343, 416-426. [CrossRef]

22. Zhou, H.; Guo, J.; Li, P.; Fan, T.; Zhang, D.; Ye, J. Leaf-architectured 3D Hierarchical Artificial Photosynthetic System of Perovskite Titanates Towards $\mathrm{CO}_{2}$ Photoreduction Into Hydrocarbon Fuels. Sci. Rep. 2013, 3, srep01667. [CrossRef]

23. Yu, M.; Zeng, Y.; Zhang, C.; Lu, X.; Zeng, C.; Yao, C.; Yang, Y.; Tong, Y. Titanium dioxide polypyrrole core-shell nanowires for all solid-state flexible supercapacitors. Nanoscale 2013, 5, 10806-10810. [CrossRef] [PubMed]

24. Xi, G.; Yue, B.; Cao, J.; Ye, J. $\mathrm{Fe}_{3} \mathrm{O}_{4} / \mathrm{WO}_{3}$ Hierarchical Core-Shell Structure: High-Performance and Recyclable Visible-Light Photocatalysis. Chem. Eur. J. 2011, 17, 5145-5154. [CrossRef] [PubMed]

25. Theerthagiri, J.; Chandrasekaran, S.; Salla, S.; Elakkiya, V.; Senthil, R.; Nithyadharseni, P.; Maiyalagan, T.; Micheal, K.; Ayeshamariam, A.; Arasu, M.V.; et al. Recent developments of metal oxide based heterostructures for photocatalytic applications towards environmental remediation. J. Solid State Chem. 2018, 267, 35-52. [CrossRef]

26. Akintelu, S.A.; Folorunso, A.S.; Folorunso, F.A.; Oyebamiji, A.K. Green synthesis of copper oxide nanoparticles for biomedical application and environmental remediation. Heliyon 2020, 6, e04508. [CrossRef]

27. Ugwu, I.M.; Igbokwe, O.A.; Igbokwe, O. Sorption of Heavy Metals on Clay Minerals and Oxides: A Review. In Advanced Sorption Process Applications; Edebali, S., Ed.; IntechOpen: London, UK, 2019.

28. Le, A.T.; Pung, S.; Sreekantan, S.; Matsuda, A.; Huynh, D.P. Mechanisms of removal of heavy metal ions by $\mathrm{ZnO}$ particles. Heliyon 2019, 5, e01440. [CrossRef]

29. Dargahi, A.; Gholestanifar, H.; Darvishi, P.; Karami, A.; Hasan, S.H.; Poormohammadi, A.; Behzadnia, A. An Investigation and Comparison of Removing Heavy Metals (Lead and Chromium) from Aqueous Solutions Using Magnesium Oxide Nanoparticles. Pol. J. Environ. Stud. 2016, 25, 557-562. [CrossRef]

30. Wang, X.; Guo, Y.; Yang, L.; Han, M.; Zhao, J.; Cheng, X. Nanomaterials as Sorbents to Remove Heavy Metal Ions in Wastewater Treatment. J. Environ. Anal. Toxicol. 2012, 2. [CrossRef]

31. Hua, M.; Zhang, S.; Pan, B.; Zhang, W.; Lv, L.; Zhang, Q. Heavy metal removal from water/wastewater by nanosized metal oxides: A review. J. Hazard. Mater. 2012, 211, 317-331. [CrossRef]

32. Kumar, A.; Kumar, S.; Krishnan, V. Perovskite-Based Materials for Photocatalytic Environmental Remediation. Environ. Chem. Sustain. World 2019, 139-165. [CrossRef]

33. Xu, P.; Xie, M.; Cheng, Z.; Zhou, Z. $\mathrm{CO}_{2}$ Capture Performance of CaO-Based Sorbents Prepared by a Sol-Gel Method. Ind. Eng. Chem. Res. 2013, 52, 12161-12169. [CrossRef]

34. Luisetto, I.; Mancini, M.R.; Della Seta, L.; Chierchia, R.; Vanga, G.; Grilli, M.L.; Stendardo, S. CaO-CaZrO 3 Mixed Oxides Prepared byAuto-Combustion for High Temperature $\mathrm{CO}_{2}$ Capture: The Effect of CaO Content on Cycle Stability. Metals 2020, 10, 750. [CrossRef]

35. Hou, J.; Cao, S.; Wu, Y.; Liang, F.; Ye, L.; Lin, Z.; Sun, L. Perovskite-based nanocubes with simultaneously improved visible-light absorption and charge separation enabling efficient photocatalytic $\mathrm{CO}_{2}$ reduction. Nano Energy 2016, 30, 59-68. [CrossRef]

36. Shi, H.; Wang, T.; Chen, J.; Zhu, C.; Ye, J.; Zou, Z. Photoreduction of Carbon Dioxide Over $\mathrm{NaNbO}_{3}$ Nanostructured Photocatalysts. Catal. Lett. 2010, 141, 525-530. [CrossRef]

37. Chen, X.; Jin, F. Photocatalytic reduction of carbon dioxide by titanium oxide based semiconductors to produce fuels. Front. Energy 2019, 13, 207-220. [CrossRef]

38. Navalón, S.; Dhakshinamoorthy, A.; Álvaro, M.; Garcia, H. Photocatalytic $\mathrm{CO}_{2}$ Reduction using Non-Titanium Metal Oxides and Sulfides. ChemSusChem 2013, 6, 562-577. [CrossRef]

39. Teramura, K.; Iguchi, S.; Mizuno, Y.; Shishido, T.; Tanaka, T. Photocatalytic Conversion of $\mathrm{CO}_{2}$ in Water over Layered Double Hydroxides. Angew. Chem. Int. Ed. 2012, 51, 8008-8011. [CrossRef]

40. Yang, Y.; Niu, S.; Han, D.; Liu, T.; Wang, G.; Li, Y. Progress in Developing Metal Oxide Nanomaterials for Photoelectrochemical Water Splitting. Adv. Energy Mater. 2017, 7. [CrossRef] 
41. Kerour, A.; Boudjadar, S.; Bourzami, R.; Allouche, B. Eco-friendly synthesis of cuprous oxide $\left(\mathrm{Cu}_{2} \mathrm{O}\right)$ nanoparticles and improvement of their solar photocatalytic activities. J. Solid State Chem. 2018, 263, 79-83. [CrossRef]

42. Wang, J.; Van Ree, T.; Wu, Y.; Zhang, P.; Gao, L. Metal oxide semiconductors for solar water splitting. Metal Oxides Energy Technol. 2018, 205-249. [CrossRef]

43. Zheng, G.; Wang, J.; Liu, H.; Murugadoss, V.; Zu, G.; Che, H.; Lai, C.; Li, H.; Ding, T.; Gao, Q.; et al. Tungsten oxide nanostructures and nanocomposites for photoelectrochemical water splitting. Nanoscale 2019, 11, 18968-18994. [CrossRef] [PubMed]

44. Tawfik, W.Z.; Hassan, M.A.; Johar, M.A.; Ryu, S.W.; Lee, J.K. Highly conversion efficiency of solar water splitting over $\mathrm{p}-\mathrm{Cu}_{2} \mathrm{O} / \mathrm{ZnO}$ photocatalyst grown on a metallic substrate. J. Catal. 2019, 374, 276-283. [CrossRef]

45. Dias, P.; Mendes, A. Hydrogen Production from Photoelectrochemical Water Splitting. In Encyclopedia of Sustainability Science and Technology; Meyers, R.A., Ed.; Springer Science and Business Media LLC: Berlin/Heidelberg, Germany, 2017; pp. 1-52.

46. Yilmaz, M.; Cirak, B.B.; Aydogan, S.; Grilli, M.L.; Biber, M. Facile electrochemical-assisted synthesis of $\mathrm{TiO}_{2}$ nanotubes and their role in Schottky barrier diode applications. Superlattices Microstruct. 2018, 113, 310-318. [CrossRef]

47. Giorgi, L.; Salernitano, E.; Makris, T.D.; Giorgi, R.; Leoni, E.; Grilli, M.; Lisi, N. Titania nanotubes self-assembled by electrochemical anodization: Semiconducting and electrochemical properties. Thin Solid Films 2016, 601, 28-34. [CrossRef]

48. Walter, M.G.; Warren, E.L.; McKone, J.R.; Boettcher, S.W.; Mi, Q.; Santori, E.A.; Lewis, N.S. Solar Water Splitting Cells. Chem. Rev. 2010, 110, 6446-6473. [CrossRef] [PubMed]

49. Grilli, M.L.; Yilmaz, M.; Aydogan, S.; Cirak, B.B. Room temperature deposition of XRD-amorphous $\mathrm{TiO}_{2}$ thin films: Investigation of device performance as a function of temperature. Ceram. Int. 2018, 44, 11582-11590. [CrossRef]

50. Jang, J.S.; Kim, H.G.; Lee, J.S. Heterojunction semiconductors: A strategy to develop efficient photocatalytic materials for visible light water splitting. Catal. Today 2012, 185, 270-277. [CrossRef]

51. Decker, F.; Cattarin, S. Photoelectrochemical Cells, Overview. In Encyclopedia of Electrochemical Power Sources; Dyer, C.K., Garche, J., Eds.; Elsevier: Amsterdam, The Netherlands, 2009.

52. Trześniewski, B.J.; Smith, W.A. Photocharged $\mathrm{BiVO}_{4}$ photoanodes for improved solar water splitting. J. Mater. Chem. A 2016, 4, 2919-2926. [CrossRef]

53. Tamirat, A.G.; Rick, J.; Dubale, A.A.; Su, W.N.; Hwang, B. Using hematite for photoelectrochemical water splitting: A review of current progress and challenges. Nanoscale Horiz. 2016, 1, 243-267. [CrossRef]

54. Ma, M.; Huang, Y.; Liu, J.; Liu, K.; Wang, Z.; Zhao, C.; Qu, S.; Wang, Z. Engineering the photoelectrochemical behaviors of $\mathrm{ZnO}$ for efficient solar water splitting. J. Semicond. 2020, 41. [CrossRef]

55. Nasrollahzadeh, M.; Sajadi, S.M.; Rostami-Vartooni, A.; Hussin, S.M. Green synthesis of CuO nanoparticles using aqueous extract of Thymus vulgaris L. leaves and their catalytic performance for $\mathrm{N}$-arylation of indoles and amines. J. Colloid Interface Sci. 2016, 466, 113-119. [CrossRef] [PubMed]

56. Thakur, P.; Kumar, V. Kinetics and thermodynamic studies for removal of methylene blue dye by biosynthesize copper oxide nanoparticles and its antibacterial activity. J. Environ. Health Sci. Eng. 2019, 17, 367-376. [CrossRef]

57. Bordbar, M.; Sharifi-Zarchi, Z.; Khodadadi, B. Green synthesis of copper oxide nanoparticles/clinoptilolite using Rheum palmatum L. root extract: High catalytic activity for reduction of 4-nitro phenol, rhodamine B, and methylene blue. J. Sol-Gel Sci. Technol. 2016, 81, 724-733. [CrossRef]

58. Mrunal, V.K.; Vishnu, A.K.; Momin, N.; Manjanna, J. $\mathrm{Cu}_{2} \mathrm{O}$ nanoparticles for adsorption and photocatalytic degradation of methylene blue dye from aqueous medium. Environ. Nanotechnol. Monit. Manag. 2019, 12, 100265. [CrossRef]

59. Nwanya, A.C.; Razanamahandry, L.C.; Bashir, A.; Ikpo, C.O.; Nwanya, S.C.; Botha, S.; Ntwampe, S.; Ezema, F.I.; Iwuoha, E.I.; Maaza, M. Industrial textile effluent treatment and antibacterial effectiveness of Zea mays L. Dry husk mediated bio-synthesized copper oxide nanoparticles. J. Hazard. Mater. 2019, 375, $281-289$. [CrossRef] [PubMed] 
60. Chauhan, M.; Sharma, B.; Kumar, R.; Chaudhary, G.R.; Hassan, A.A.; Kumar, S. Green synthesis of CuO nanomaterials and their proficient use for organic waste removal and antimicrobial application. Environ. Res. 2019, 168, 85-95. [CrossRef]

61. Sundaramurthy, J.; Kumar, P.S.; Kalaivani, M.; Thavasi, V.; Mhaisalkar, S.G.; Ramakrishna, S. Superior photocatalytic behaviour of novel 1D nanobraid and nanoporous $\alpha-\mathrm{Fe}_{2} \mathrm{O}_{3}$ structures. RSC Adv. 2012, 2, 8201-8208. [CrossRef]

62. Zhang, G.-Y.; Feng, Y.; Xu, Y.-Y.; Gao, D.-Z.; Sun, Y.-Q. Controlled synthesis of mesoporous $\alpha-\mathrm{Fe}_{2} \mathrm{O}_{3}$ nanorods and visible light photocatalytic property. Mater. Res. Bull. 2012, 47, 625-630. [CrossRef]

63. Liu, G.; Deng, Q.; Wang, H.; Ng, D.H.L.; Kong, M.; Cai, W.; Wang, G. Micro/nanostructured $\alpha$-Fe ${ }_{2} \mathrm{O}_{3}$ spheres: Synthesis, characterization, and structurally enhanced visible-light photocatalytic activity. J. Mater. Chem. 2012, 22, 9704-9713. [CrossRef]

64. Xu, L.; Xia, J.; Wang, K.; Wang, L.; Li, H.; Xu, H.; Huang, L.; He, M. Ionic liquid assisted synthesis and photocatalytic properties of $\alpha-\mathrm{Fe}_{2} \mathrm{O}_{3}$ hollow microspheres. Dalton Trans. 2013, 42, 6468-6477. [CrossRef]

65. Isaev, A.; Aliev, Z.M.; Adamadzieva, N.K.; Alieva, N.A.; Magomedova, G.A. The photocatalytic oxidation of azo dyes on Fe2O3 nanoparticles under oxygen pressure. Nanotechnol. Russ. 2009, 4, 475-479. [CrossRef]

66. Mahmoud, M.E.; Amira, M.F.; Zaghloul, A.A.; Ibrahim, G.A. High performance microwave-enforced solid phase extraction of heavy metals from aqueous solutions using magnetic iron oxide nanoparticles-protected-nanosilica. Sep. Purif. Technol. 2016, 163, 169-172. [CrossRef]

67. Guo, M.; Fung, M.; Fang, F.; Chen, X.; Ng, A.M.C.; Djurišić, A.B.; Chan, W. ZnO and TiO 2 1D nanostructures for photocatalytic applications. J. Alloys Compd. 2011, 509, 1328-1332. [CrossRef]

68. Quarta, A.; Novais, R.M.; Bettini, S.; Iafisco, M.; Pullar, R.C.; Piccirillo, C. A sustainable multi-function biomorphic material for pollution remediation or UV absorption: Aerosol assisted preparation of highly porous ZnO-based materials from cork templates. J. Environ. Chem. Eng. 2019, 7, 102936. [CrossRef]

69. Chen, X.; Wu, Z.; Liu, D.; Gao, Z. Preparation of ZnO Photocatalyst for the Efficient and Rapid Photocatalytic Degradation of Azo Dyes. Nanoscale Res. Lett. 2017, 12, 1-10. [CrossRef]

70. Amini, M.; Ashrafi, M. Photocatalytic degradation of some organic dyes under solar light irradiation using $\mathrm{TiO}_{2}$ and $\mathrm{ZnO}$ nanoparticles. Nano Chem Res. 2016, 1, 79-86.

71. Tayade, R.J.; Surolia, P.K.; Kulkarni, R.G.; Jasra, R.V. Photocatalytic degradation of dyes and organic contaminants in water using nanocrystalline anatase and rutile $\mathrm{TiO}_{2}$. Sci. Technol. Adv. Mater. 2007, 8, 455-462. [CrossRef]

72. Reza, K.M.; Kurny, A.S.W.; Gulshan, F. Parameters affecting the photocatalytic degradation of dyes using $\mathrm{TiO}_{2}$ : A review. Appl. Water Sci. 2017, 7, 1569-1578. [CrossRef]

73. Mohammadi, A.; Fallah Moafi, H.; Mohammadi, A.; Karimi, A.; Fallah Moafi, H. Adsorption and Photocatalytic Properties of Surface-Modified $\mathrm{TiO}_{2}$ Nanoparticles for Methyl Orange removal from Aqueous Solutions Organic Colorants. Prog. Color Colorants Coat. 2016, 9, 247-258.

74. Malini, B.; Raj, G.A.G. C,N and S-doped $\mathrm{TiO}_{2}$-characterization and photocatalytic performance for rose bengal dye degradation under day light. J. Environ. Chem. Eng. 2018, 6, 5763-5770. [CrossRef]

75. Goutam, S.P.; Saxena, G.; Singh, V.; Yadav, A.K.; Bharagava, R.N.; Thapa, K.B. Green synthesis of $\mathrm{TiO}_{2}$ nanoparticles using leaf extract of Jatropha curcas L. for photocatalytic degradation of tannery wastewater. Chem. Eng. J. 2018, 336, 386-396. [CrossRef]

76. Khan, S.B.; Hou, M.; Shuang, S.; Zhang, Z. Morphological influence of $\mathrm{TiO}_{2}$ nanostructures (nanozigzag, nanohelics and nanorod) on photocatalytic degradation of organic dyes. Appl. Surf. Sci. 2017, 400, 184-193. [CrossRef]

77. Mironyuk, I.; Tatarchuk, T.; Naushad, M.; Vasylyeva, H.; Mykytyn, I. Highly efficient adsorption of strontium ions by carbonated mesoporous $\mathrm{TiO}_{2}$. J. Mol. Liq. 2019, 285, 742-753. [CrossRef]

78. Yao, S.; Zhang, X.; Qu, F.; Umar, A.; Wu, X. Hierarchical $\mathrm{WO}_{3}$ nanostructures assembled by nanosheets and their applications in wastewater purification. J. Alloys Compd. 2016, 689, 570-574. [CrossRef]

79. Yao, S.; Qu, F.; Wang, G.; Wu, X. Facile hydrothermal synthesis of $\mathrm{WO}_{3}$ nanorods for photocatalysts and supercapacitors. J. Alloys Compd. 2017, 724, 695-702. [CrossRef]

80. Yu, J.; Qi, L. Template-free fabrication of hierarchically flower-like tungsten trioxide assemblies with enhanced visible-light-driven photocatalytic activity. J. Hazard. Mater. 2009, 169, 221-227. [CrossRef] [PubMed] 
81. Adhikari, S.; Chandra, K.S.; Kim, D.-H.; Madras, G.; Sarkar, D. Understanding the morphological effects of $\mathrm{WO}_{3}$ photocatalysts for the degradation of organic pollutants. Adv. Powder Technol. 2018, 29, 1591-1600. [CrossRef]

82. Wang, Z.; Chu, D.; Wang, L.; Wang, L.; Hu, W.; Chen, X.; Yang, H.; Sun, J. Facile synthesis of hierarchical double-shell $\mathrm{WO}_{3}$ microspheres with enhanced photocatalytic activity. Appl. Surf. Sci. 2017, 396, 492-496. [CrossRef]

83. Guo, X.; Qin, X.; Xue, Z.; Zhang, C.; Sun, X.; Hou, J.; Wang, T. Morphology-controlled synthesis of $\mathrm{WO}_{2.72}$ nanostructures and their photocatalytic properties. RSC Adv. 2016, 6, 48537-48542. [CrossRef]

84. Salari, H.; Kohantorabi, M. Facile template-free synthesis of new $\alpha-\mathrm{MnO}_{2}$ nanorod/silver iodide $\mathrm{p}-\mathrm{n}$ junction nanocomposites with high photocatalytic performance. New J. Chem. 2020, 44, 7401-7411. [CrossRef]

85. Zhang, Y.; Liu, C.-H.; Zhu, G.; Huang, X.; Liu, W.; Hu, W.; Song, M.; He, W.; Liu, J.; Zhai, J. Piezotronic-effect-enhanced $\mathrm{Ag}_{2} \mathrm{~S} / \mathrm{ZnO}$ photocatalyst for organic dye degradation. RSC Adv. 2017, 7, 48176-48183. [CrossRef]

86. Türkyılmaz, Ş.Ş.; Güy, N.; Özacar, M. Photocatalytic efficiencies of Ni, Mn, Fe and Ag doped ZnO nanostructures synthesized by hydrothermal method: The synergistic/antagonistic effect between $\mathrm{ZnO}$ and metals. J. Photochem. Photobiol. A Chem. 2017, 341, 39-50. [CrossRef]

87. Chang, Y.C.; Guo, J.Y.; Chen, C.M.; Di, H.W.; Hsu, C.C. Construction of CuO/ $\mathrm{In}_{2} \mathrm{~S}_{3} / \mathrm{ZnO}$ heterostructure arrays for enhanced photocatalytic efficiency. Nanoscale 2017, 9, 13235-13244. [CrossRef] [PubMed]

88. Li, X.; Li, X.; Zhu, B.; Wang, J.; Lan, H.; Chen, X. Synthesis of porous ZnS, ZnO and ZnS/ZnO nanosheets and their photocatalytic properties. RSC Adv. 2017, 7, 30956-30962. [CrossRef]

89. Donat, F.; Corbel, S.; Alem, H.; Pontvianne, S.; Balan, L.; Medjahdi, G.; Schneider, R. ZnO nanoparticles sensitized by CuInZnxS2+x quantum dots as highly efficient solar light driven photocatalysts. Beilstein J. Nanotechnol. 2017, 8, 1080-1093. [CrossRef]

90. Hong, D.; Zang, W.; Guo, X.; Fu, Y.; He, H.; Sun, J.; Xing, L.; Liu, B.; Xue, X. High Piezo-photocatalytic Efficiency of CuS/ZnO Nanowires Using Both Solar and Mechanical Energy for Degrading Organic Dye. ACS Appl. Mater. Interfaces 2016, 8, 21302-21314. [CrossRef]

91. Chanu, I.; Krishnamurthi, P.; Manoharan, P.T. Effect of Silver on Plasmonic, Photocatalytic, and Cytotoxicity of Gold in AuAgZnO Nanocomposites. J. Phys. Chem. C 2017, 121, 9077-9088. [CrossRef]

92. Chen, D.; Li, T.; Chen, Q.; Gao, J.; Fan, B.; Li, J.; Li, X.; Zhang, R.; Sun, J.; Gao, L. Hierarchically plasmonic photocatalysts of $\mathrm{Ag} / \mathrm{AgCl}$ nanocrystals coupled with single-crystalline $\mathrm{WO}_{3}$ nanoplates. Nanoscale 2012, 4, 5431-5439. [CrossRef]

93. Yuan, X.; Jiang, L.; Chen, X.; Leng, L.; Wang, H.; Wu, Z.; Xiong, T.; Liang, J.; Zeng, G. Highly efficient visible-light-induced photoactivity of Z-scheme $\mathrm{Ag}_{2} \mathrm{CO}_{3} / \mathrm{Ag} / \mathrm{WO}_{3}$ photocatalysts for organic pollutant degradation. Environ. Sci. Nano 2017, 4, 2175-2185. [CrossRef]

94. Hu, Y.; Zheng, H.; Xu, T.; Xu, N.; Ma, H. Highly efficient $\mathrm{Ag}_{6} \mathrm{Si}_{2} \mathrm{O}_{7} / \mathrm{WO}_{3}$ photocatalyst based on heterojunction with enhanced visible light photocatalytic activities. RSC Adv. 2016, 6, 103289-103295. [CrossRef]

95. Liu, J.-F.; Zhao, Z.S.; Jiang, G.B. Coating $\mathrm{Fe}_{3} \mathrm{O}_{4}$ Magnetic Nanoparticles with Humic Acid for High Efficient Removal of Heavy Metals in Water. Environ. Sci. Technol. 2008, 42, 6949-6954. [CrossRef]

96. Esmat, M.; Farghali, A.A.; Khedr, M.H.; El-Sherbiny, I.M. Alginate-based nanocomposites for efficient removal of heavy metal ions. Int. J. Biol. Macromol. 2017, 102, 272-283. [CrossRef] [PubMed]

97. Rao, M.P.; Musthafa, S.; Wu, J.J.; Anandan, S. Facile synthesis of perovskite $\mathrm{LaFeO}_{3}$ ferroelectric nanostructures for heavy metal ion removal applications. Mater. Chem. Phys. 2019, 232, 200-204. [CrossRef]

98. Lasheen, M.; El-Sherif, I.Y.; Sabry, D.Y.; El-Wakeel, S.; El-Shahat, M. Adsorption of heavy metals from aqueous solution by magnetite nanoparticles and magnetite-kaolinite nanocomposite: Equilibrium, isotherm and kinetic study. Desalination Water Treat. 2016, 57, 17421-17429. [CrossRef]

99. Koli, P.B.; Kapadnis, K.H.; Deshpande, U.G.; Patil, M.R. Fabrication and characterization of pure and modified $\mathrm{Co}_{3} \mathrm{O}_{4}$ nanocatalyst and their application for photocatalytic degradation of eosine blue dye: A comparative study. J. Nanostructure Chem. 2018, 8, 453-463. [CrossRef]

100. Fallah Shojaei, A.; Shams-Nateri, A.; Ghomashpasand, M. Comparative study of photocatalytic activities of magnetically separable $\mathrm{WO}_{3} / \mathrm{TiO}_{2} / \mathrm{Fe}_{3} \mathrm{O}_{4}$ nanocomposites and $\mathrm{TiO}_{2}, \mathrm{WO}_{3} / \mathrm{TiO}_{2}$ and $\mathrm{TiO}_{2} / \mathrm{Fe}_{3} \mathrm{O}_{4}$ under visible light irradiation. Superlattices Microstruct. 2015, 88, 211-224. [CrossRef]

101. Cao, G.S.; Wang, G.L.; Liu, M.X.; Bai, Y.J. Photocatalytic removal of Rhodamine B using $\mathrm{Fe}_{3} \mathrm{O}_{4} / \mathrm{BiOBr}$ magnetic microsphere under visible-light irradiation. Micro Nano Lett. 2015, 10, 115-118. [CrossRef] 
102. Thiruppathi, M.; Kumar, P.S.; Devendran, P.; Ramalingan, C.; Swaminathan, M.; Nagarajan, E. Ce@ $\mathrm{TiO}_{2}$ nanocomposites: An efficient, stable and affordable photocatalyst for the photodegradation of diclofenac sodium. J. Alloys Compd. 2018, 735, 728-734. [CrossRef]

103. Nasr, O.; Mohamed, O.; Al-Shirbini, A.-S.; Abdel-Wahab, A.-M. Photocatalytic degradation of acetaminophen over Ag, Au and Pt loaded TiO2 using solar light. J. Photochem. Photobiol. A Chem. 2019, 374, 185-193. [CrossRef]

104. Kumar, S.; Sharma, S.; Sood, S.; Umar, A.; Kansal, S.K. Bismuth sulfide $\left(\mathrm{Bi}_{2} \mathrm{~S}_{3}\right)$ nanotubes decorated $\mathrm{TiO}_{2}$ nanoparticles heterojunction assembly for enhanced solar light driven photocatalytic activity. Ceram. Int. 2016, 42, 17551-17557. [CrossRef]

105. Cerrón-Calle, G.A.; Aguirre, A.A.; Luyo, C.; Garcia-Segura, S.; Alarcón,H. Photoelectrocatalytic decolorization of azo dyes with nano-composite oxide layers of $\mathrm{ZnO}$ nanorods decorated with Ag nanoparticles. Chemosphere 2019, 219, 296-304. [CrossRef] [PubMed]

106. Ammar, S.H.; Kareem, Y.S.; Ali, A.D. Photocatalytic oxidative desulfurization of liquid petroleum fuels using magnetic $\mathrm{CuO}-\mathrm{Fe}_{3} \mathrm{O}_{4}$ nanocomposites. J. Environ. Chem. Eng. 2018, 6, 6780-6786. [CrossRef]

Publisher's Note: MDPI stays neutral with regard to jurisdictional claims in published maps and institutional affiliations.

(C) 2020 by the authors. Licensee MDPI, Basel, Switzerland. This article is an open access article distributed under the terms and conditions of the Creative Commons Attribution (CC BY) license (http://creativecommons.org/licenses/by/4.0/). 